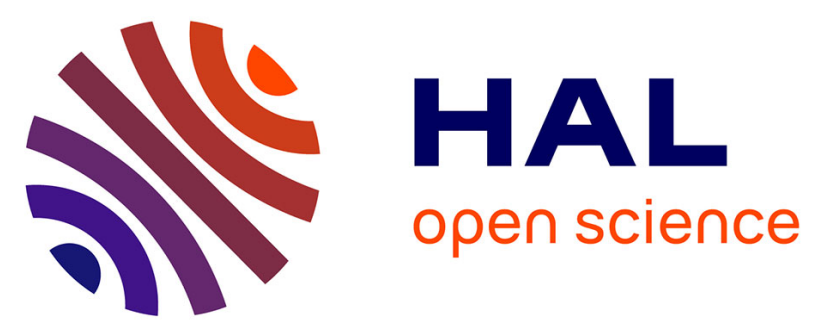

\title{
Elemental weathering fluxes and saprolite production rate in a Central African lateritic terrain (Nsimi, South Cameroon)
}

Jean-Jacques Braun, Jean-Christophe Maréchal, Jean Riotte, Jean-Loup Boeglin, Jean-Pierre Bedimo Bedimo, Jules Remy Ndam Ngoupayou, Brunot Nyeck, Henri Robain, Muddu Sekhar, Stéphane Audry, et al.

\section{To cite this version:}

Jean-Jacques Braun, Jean-Christophe Maréchal, Jean Riotte, Jean-Loup Boeglin, Jean-Pierre Bedimo Bedimo, et al.. Elemental weathering fluxes and saprolite production rate in a Central African lateritic terrain (Nsimi, South Cameroon). Geochimica et Cosmochimica Acta, 2012, 99, pp.243-270. 10.1016/j.gca.2012.09.024 . hal-00806642

\section{HAL Id: hal-00806642 https://hal.science/hal-00806642}

Submitted on 3 Apr 2013

HAL is a multi-disciplinary open access archive for the deposit and dissemination of scientific research documents, whether they are published or not. The documents may come from teaching and research institutions in France or abroad, or from public or private research centers.
L'archive ouverte pluridisciplinaire HAL, est destinée au dépôt et à la diffusion de documents scientifiques de niveau recherche, publiés ou non, émanant des établissements d'enseignement et de recherche français ou étrangers, des laboratoires publics ou privés. 


\title{
Elemental weathering fluxes and saprolite production rate in a Central African lateritic terrain (Nsimi, South Cameroon)
}

\author{
Jean-Jacques Braun ${ }^{\mathrm{a}, \mathrm{b}, *}$, Jean-Christophe Marechal ${ }^{\mathrm{c}}$, Jean Riotte ${ }^{\mathrm{a}, \mathrm{b}}$, \\ Jean-Loup Boeglin ${ }^{\mathrm{b}}$, Jean-Pierre Bedimo Bedimo ${ }^{\mathrm{d}}$, Jules Remy Ndam Ngoupayou ${ }^{\mathrm{e}}$, \\ Brunot Nyeck $^{\mathrm{e}}$, Henri Robain ${ }^{\mathrm{f}}$, M. Sekhar ${ }^{\mathrm{a}, \mathrm{g}}$, Stéphane Audry ${ }^{\mathrm{b}}$, Jérôme Viers ${ }^{\mathrm{b}}$ \\ a Indo-French Cell for Water Sciences, IISc-IRD Joint International Laboratory, IISc, Bangalore 560012, India \\ ${ }^{\mathrm{b}}$ GET-OMP, UMR 5563 CNRS/Univ. P. Sabatier/IRD, 14 Avenue E. Belin, F-31400 Toulouse, France \\ ${ }^{\mathrm{c}}$ BRGM-Service Eau, 1039, Rue de Pinville, 34000 Montpellier, France \\ ${ }^{\mathrm{d}}$ Institut de Recherche Géologique et Minière, Centre de Recherche Hydrologique, BP 4110 Yaoundé, Cameroon \\ ${ }^{\mathrm{e}}$ Department of Earth Sciences, University of Yaoundé I, BP 512 Yaoundé, Cameroon \\ ${ }^{\mathrm{f}}$ BIOEMCO UMR 7618 UPMC - CNRS - INRA - ENS - ENSCP - INA-PG Campus Jussieu, Tour 46/56, 2ème étage, \\ 4, Place Jussieu 75252 Paris Cedex 05, France \\ ${ }^{\mathrm{g}}$ Civil Engineering Department, IISc, Bangalore 560012, India
}

Received 13 June 2011; accepted in revised form 13 September 2012; available online 27 September 2012

\begin{abstract}
The comparison between contemporary and long-term weathering has been carried out in the Small Experimental Watershed (SEW) of Nsimi, South Cameroon in order to quantify the export fluxes of major and trace elements and the residence time of the lateritic weathering cover. We focus on the hillside system composed of a thick lateritic weathering cover topped by a soil layer. This study is built on the recent improvements of the hillside hydrological functioning and on the analyses of major and trace elements.

The mass balance calculation at the weathering horizon scale performed with the parent rock as reference indicates (i) strong depletion profiles for alkalis $(\mathrm{Na}, \mathrm{K}, \mathrm{Rb})$ and alkaline earths $(\mathrm{Mg}, \mathrm{Ca}, \mathrm{Sr}, \mathrm{Ba})$, (ii) moderate depletion profiles for $\mathrm{Si}, \mathrm{P}, \mathrm{Cd}, \mathrm{Cu}, \mathrm{Zn}, \mathrm{Ni}$ and $\mathrm{Co}$, (iii) depletion/enrichment profiles for Al, Ga, Ge, Sn, Pb, LREE, HREE, Y, U, Fe, V, Cr, $\mathrm{Mn}$. It is noteworthy that (i) $\mathrm{Mn}$ and $\mathrm{Ce}$ are not significantly redistributed according to oxidative processes as it is the case for Fe, $\mathrm{V}$ and $\mathrm{Cr}$, and (ii) Ge is fractionated compared to silica with enrichment in Fe-rich horizons. The calculations performed for the topsoil with iron crust as parent material reference reveal that the degradation of the iron crust is accompanied by the loss of most of the constituting elements, among which are those specifically accumulated as the redox sensitive elements $(\mathrm{Fe}, \mathrm{V}, \mathrm{Cr})$ and iron oxide related elements like Th.

The overall current elemental fluxes from the hillside system at the springs and the seepage zones are extremely low due to the inert lateritic mineralogy. Ninety-four percent of the whole $\mathrm{Na}$ flux generated from the hillside corrected from atmospheric deposits $(77 \mathrm{~mol} / \mathrm{ha} / \mathrm{yr})$ represents the current weathering rates of plagioclase (oligoclase) in the system, the other remaining $6 \%$ may be attributed to the dissolution of hornblende. The silica hillside flux is $300 \mathrm{~mol} / \mathrm{ha} / \mathrm{yr}$ and can be mostly attributed to the plagioclase and kaolinite dissolution. Al and Ga are exported from the lateritic regolith and maybe due to the dissolution of kaolinite crystals. Compared to the other immobile elements ( $\mathrm{Zr}, \mathrm{Hf}, \mathrm{Nb}$ and $\mathrm{Th}$ ), Ti is significantly exported. Among redox-sensitive elements ( $\mathrm{Fe}, \mathrm{V}, \mathrm{Cr}, \mathrm{Mn}, \mathrm{Ce}$ ), only $\mathrm{Ce}$ and $\mathrm{Mn}$ are exported out of the hillside system. The other elements $(\mathrm{Fe}, \mathrm{V}, \mathrm{Cr})$ are likely able to be mobilized but over a short distance only. $\mathrm{Rb}, \mathrm{Sr}, \mathrm{Ba}, \mathrm{Ni}, \mathrm{Cu}, \mathrm{Zn}$ are affected by export
\end{abstract}

\footnotetext{
* Corresponding author at: Indo-French Cell for Water Sciences, IISc-IRD Joint International Laboratory, IISc, Bangalore 560012, India. Fax: +91803600223 .

E-mail address: jjbraun1@gmail.com (J.-J. Braun).
} 
processes. LREE and Y are exported but in very low amounts (in the range from $\mu \mathrm{mol} / \mathrm{ha} / \mathrm{yr}$ to mmol/ha/yr) while HREE and $\mathrm{U}$ are exported in negligible quantities.

A first attempt is carried out to compare the mature ridge top profile from Nsimi SEW with the immature ridge top weathering profile from the Mule Hole SEW (South India), developed on similar granodioritic basement, in order to get deeper insight into (i) the contemporary saprolite production rates and (ii) the combined effect of precipitation (in terms of Mean Annual Rainfall, MAR) and evapotranspiration on the aggressiveness of the draining solutions. Considering (i) the contemporary $\mathrm{Na}$ flux as representative of the dissolution of plagioclase crystals and conservative during saprolitization processes and (ii) steady state of the inter-annual recharge (R) over a 10 years period, the current saprolite production rates $\left(\sigma_{r}\right)$ are of $22 \mathrm{~mm} / \mathrm{kyr}$ for Mule Hole SEW and $2 \mathrm{~mm} / \mathrm{kyr}$ for Nsimi SEW, respectively. Even with a very low R/MAR ratio (0.04) compared to Nsimi, the chemical weathering at Mule Hole is active and related to the groundwater exports. At Mule Hole, plagioclase crystals are still present in the saprolite and the soil cover leading to a diffuse weathering front. The high Nsimi R/ MAR ratio (0.2) allows the solution to be still aggressive with respect to the plagioclase and other weatherable minerals at the bedrock interface resulting in their complete breakdown in a few centimetres (sharp weathering front) leading to a mature saprolite.

For the Nsimi SEW, if we consider (i) the low contemporary saprolite production rate ( $2 \mathrm{~mm} / \mathrm{kyr}$ ), (ii) the Miocene age (average $15 \mathrm{Myr}$ ) of the South Cameron Plateau landscape and (ii) the limited movement of Africa continent since Eocene, the long term saprolite production rate should have remained in its lower range, from 2 to $10 \mathrm{~m} / \mathrm{Myr}$. This suggests that, for thick weathering profiles the migration of the weathering front into the bedrock occurs at a relatively uniform rate regardless of present-day climatic conditions. Climate variation leading to the alternation of setup of savanna or humid forest will have an effect on physical erosion rather than chemical erosion for such deep weathering profiles.

(c) 2012 Elsevier Ltd. All rights reserved.

\section{INTRODUCTION}

Chemical weathering in the Critical Zone can be addressed from two perspectives (White, 2008; Brantley and White, 2009; Brantley and Lebedeva, 2011). This can be either on a geologic time scale based on solid-state elemental, isotopic and mineralogical changes in weathering products relative to the parent rock or on a contemporary time scale based on the present day solute compositions and fluxes. However, combining both approaches offers a powerful method of improving the quantitative modelling of dynamics within the Critical Zone (i.e. saprolite and soil production rates, cycling of carbon, nutrients and potentially toxic element migration). Such studies are particularly crucial in our ever-changing environment and especially in those systems affected by both climate variations and human activities (Velbel, 1993; Riebe et al., 2003; Anderson et al., 2008, 2007; Brantley, 2007, 2008, 2010; Goddéris et al., 2009).

Lateritic terrains cover most of the shield landscapes in the humid Tropics. They have to be considered as both palaeoclimatic records and feed-through reactors and representative of optimal conditions for chemical weathering (Kisakurek et al., 2004; Braun et al., 2005; West et al., 2005; Anderson et al., 2007; Wimpenny et al., 2007). In such regions, (Godderis et al., 2008) determined that silicate weathering in the warm humid tropical belt is five times less sensitive to continental runoff than in mid-latitude temperate climate due to the shield effect of the deep mature weathering profiles. However, the integrated effects of intrinsic changes in mineral properties and abundances, as well as extrinsic long-term changes in climate and vegetation, soil permeability and topography, commonly only reach maturity over periods of tens of thousands to millions of years (Nahon, 1991; Tardy, 1993; Thomas, 1994; Tardy and Roquin, 1998). Moreover, most of these lateritic covers have developed in those regions where prevailing transportlimited conditions have been favourable to deep and prolonged chemical weathering (Nash and McLaren, 2007; Retallack, 2010; Tardy and Roquin, 1998; Widdowson, 2003, 2007).

Despite the heterogeneous structures and textures observed in these widespread lateritic covers, their mineralogical composition is predictably monotonous consisting chiefly of the secondary minerals, kaolinite, gibbsite, goethite, and hematite (Schellmann, 1986; Aleva, 1994). Studies of U/Th disequilibrium (Dequincey et al., 2002; Chabaux et al., 2003) and radiation-induced defects in kaolinite (Balan et al., 2005) suggest that each horizon of the lateritic profile behaves independently, reflecting the superimposition of further remobilization effects upon older formation steps. Although the petrology, mineralogy and geochemistry of lateritic profiles developed on silicate rocks have been extensively studied, the quantification of the chemical fluxes within the regolith and, hence, the saprolite and soil production rates remain poorly constrained. Most of the attempts in the Tropics have been carried out with stream chemistry, which may be significantly influenced by processes occurring in the hyporeic zones (e.g. swamp, alluvial valley) (Edmond et al., 1995; Boeglin and Probst, 1998).

In tectonically quiescent shield areas, uplift is minimum and the only variation of base level is likely to have resulted from eustatic variation such as that resulting from the advance and retreat of ice sheets in mid and boreal latitudes. Thus, in general, the balance between erosion and weathering rates has been in favour of deepening of the regolith by chemical weathering, rather than one of regional erosive stripping. In addition, successive periods of high and low ferruginisation (leading to the formation of different gener- 
ations of iron crust) have resulted from climate changes (Tardy and Roquin, 1998; Retallack, 2010).

The 'small experimental watershed' (SEW) of Nsimi has been previously described (Braun et al., 2005) and is considered representative of the lateritic tropical environment of the South Cameroon plateau which is itself typified of multiconvex landform developed on granitic terrains (Migon, 2006, 2009; Thomas, 1994). The South Cameroon Plateau has remained at equatorial latitudes since Eocene $(46 \pm 8 \mathrm{Myr})$ as a consequence of the limited movement of Africa continent (Parrish et al., 1982) and so the tropical paleo-climatic conditions are unlikely to have altered significantly during this prolonged period.

The Nsimi SEW has been under investigation for hydrology and biogeochemistry for the last 15 years. It is developed on a granito-gneissic basement and may be considered as two geomorphologically-controlled systems: (i) a hillside lateritic system and (ii) a hydromorphic swamp system. The mineralogy and geochemistry of the solid phases (i.e. lateritic products) and the water chemistry have been extensively studied within both systems (Viers et al., 1997; Oliva et al., 1999; Braun et al., 2005). The contribution of phytoliths to the suspended load of biogenic silica was also investigated (Cary et al., 2005), whilst isotopic fractionation of $\mathrm{Nd}, \mathrm{Fe}$ and $\mathrm{Zn}$ in the different reservoirs of the system were discussed by (Viers and Wasserburg, 2004; Viers et al., 2007; Poitrasson et al., 2008). To date, quantitative flux studies have only focused on the organic-rich water draining the swamp system and contemporary fluxes for major (Ca, Na, Mg, K, Fe, Al, Ti) and for selected trace elements $(\mathrm{Th}, \mathrm{Zr})$ were assessed at the outlet of the SEW (Braun et al., 2005). These studies showed that the organic-rich surface waters enhanced the mobilisation and transfer of $\mathrm{Al}$ and $\mathrm{Fe}$ and even the highly charged transition metals such as $\mathrm{Th}$, Ti and $\mathrm{Zr}$ (Braun et al., 2005). However, the specific contribution of the hillside lateritic system to the chemical weathering fluxes remains poorly understood, especially for trace elements.

Building on the long-term hydrological and geochemical monitoring of the Nsimi SEW, (Maréchal et al., 2011a) recently described the main hydrological processes; here the Chloride Mass Balance (CMB) was used to compute on a yearly basis the hillslope groundwater discharge to the swamp zone while the contributions of various source waters to two short storm events of a few hours duration were determined by end-member mixing analysis. The current study is based upon these earlier assessments, however here we refine the contemporary fluxes for major and trace elements in the hillside lateritic system and determine their contribution to the outlet flux. These contemporary fluxes are then compared with the mass balance calculation elemental gain/loss in a hill-top weathering profile.

In order to refine the elemental transfers in lateritic covers developed on silicate basement and to get deeper insight into (i) the contemporary saprolite production rates and (ii) the combined effect of precipitation and evapotranspiration on the aggressiveness of the draining solutions, a first attempt has been carried out both on the studied mature profile of the Nsimi SEW and with the immature ridge top weathering profile from the Mule Hole SEW (South India), developed on a similar granodioritic basement (Descloitres et al., 2007; Braun et al., 2009; Marechal et al., 2009; Ruiz et al., 2010; Violette et al., 2010; Soumya et al., 2011; Maréchal et al., 2011b). Finally, taking into account the results of the present study and the known history of the South Cameroon landscape, we infer the average saprolite production rate on a long term basis.

\section{SETTINGS}

The landform of the South Cameroon Plateau, now at a mean elevation of $700 \mathrm{~m}$, namely "Interior Erosion Surface", corresponds to the dismantling of an old iron crust undergoing more humid climatic conditions (Bilong et al., 1992; Beauvais, 1999; Bitom et al., 2004). This multiconvex landform is composed of rather closely spaced hilly compartments, typically of few hundred metres in diameter, separated by flat swampy valleys of variable stretch from 50 to $500 \mathrm{~m}$ width (Bitom et al., 2004). The hills are covered by thick weathering formation capped by ferruginous soft nodular layers containing fragments of iron crust, overlaid by soft clayey topsoil. The topsoil is the substratum of the rain forest and diverse crops and its fragility has been clearly pointed out. The age of the erosion surface has been assessed by different authors (Segalen, 1967; Fritsch, 1978; Morin, 1989) based on relative geomorphic data and span from Eocene to Quaternary (Tardy and Roquin, 1998). However, (Tardy and Roquin, 1998) suggested that the age of the erosion surface is likely Miocene based on further studies (Morin, 1989).

The Nyong river basin is located in the tropical rainforest zone between the latitude $2^{\circ} 48^{\prime} \mathrm{N}$ and $4^{\circ} 32^{\prime} \mathrm{N}$ (Fig. 1), primarily on the South Cameroon Plateau. The Nsimi SEW $\left(3^{\circ} 10^{\prime} \mathrm{N}-11^{\circ} 51^{\prime} \mathrm{E}\right)$ belongs to the Upper Nyong river basin and an extended description of this 60 ha watershed is given in (Braun et al., 2005). The Nsimi SEW presents the contemporary weathering conditions for a mature weathering cover under humid climate with the alternation of two rainy and dry seasons throughout the hydrological year. Over the period from 1994 to 2010, the MAR is $1640 \pm 260 \mathrm{~mm} / \mathrm{yr}$ with a coefficient of variation of $16 \%$ (data from http://bvet.omp.obs-mip.fr). The rainforest vegetation induces an Actual EvapoTranspiration (AET) of $1270 \mathrm{~mm} / \mathrm{yr}(76.5 \%$ of the MAR). The vegetation cover on the hillsides limits the erosion.

The parent rock of the Nsimi SEW is composed of two intermingled granitoid rocks: a gray blue granodiorite and a leucocratic monzogranite. Numerous quartz seams crosscut the granitoid body. The mineralogy of the granodiorite is composed of quartz, oligoclase, hornblende, $\mathrm{K}$-feldspar, biotite, magnetite and titano-magnetite. Accessories (less than $1 \%$ ) are zircon, monazite and apatite. The mineralogy of the granite is composed of quartz, K-feldspar, albite, biotite and accessories as epidote, magnetite, ilmenite, titanite and zircon.

The hillside weathering cover is composed of a thick variegated saprolite superimposed by lateritic horizons (i.e. mottled clay, carapace and iron crust) topped by a soft clayey topsoil. The presence of the crosscutting quartz seams within the horizons undergoing lateritization pro- 


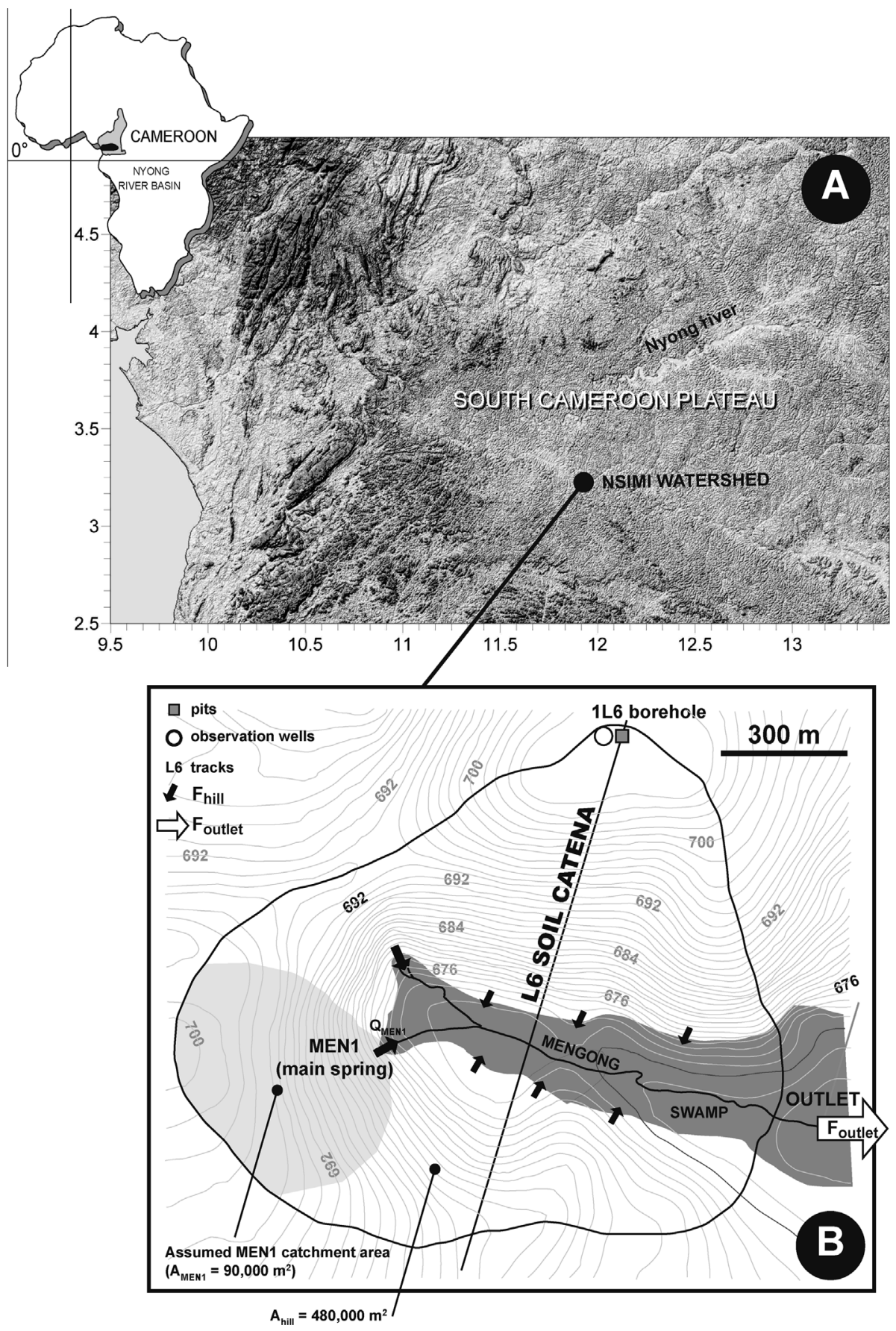

Fig. 1. (A) Location of the Nsimi Small Experimental Watershed (SEW) in the South Cameroon plateau and (B) map of the Nsimi SEW showing the swamp area (shaded area), the main catena L6, the pit/bore hole 1L6, the MEN1 spring and its drainage area $\left(A_{\mathrm{MEN} 1}, 19 \%\right.$ of the hillside drainage area $\left.A_{\text {hill }}\right)$ and the outlet. The fluxes from hillside ( $F_{\text {hill }}$, black arrows) and at the watershed outlet $\left(F_{\text {outlet }}\right.$, white arrow) are also indicated. The detailed calculations are indicated in the discussion part.

cesses as mottled clay, carapace and iron crust attests to their in situ development. The thickness and distribution of these layers depend on the topographic position. The saprolite has a variable thickness varying from 0 to $20 \mathrm{~m}$ at the watershed scale. In the hillside system, the thickness of the lateritic layers and of the top soil is $15 \mathrm{~m}$ at the top of the North hill (pit 1L6, Fig. 2); the depth however, decreases progressively towards the flat swamp.
The maturity of the weathering cover is marked by the complete breakdown of plagioclase crystals since the inception of saprolitization processes at the weathering front transforming the parent rocks into a loose variegated material. Hence, the waterlogged saprolite-bedrock interface (i.e. the saprolite production zone) is a steep threshold where, in a few centimetres, the rock forming minerals, except quartz and zircon, are completely weathered and/or 

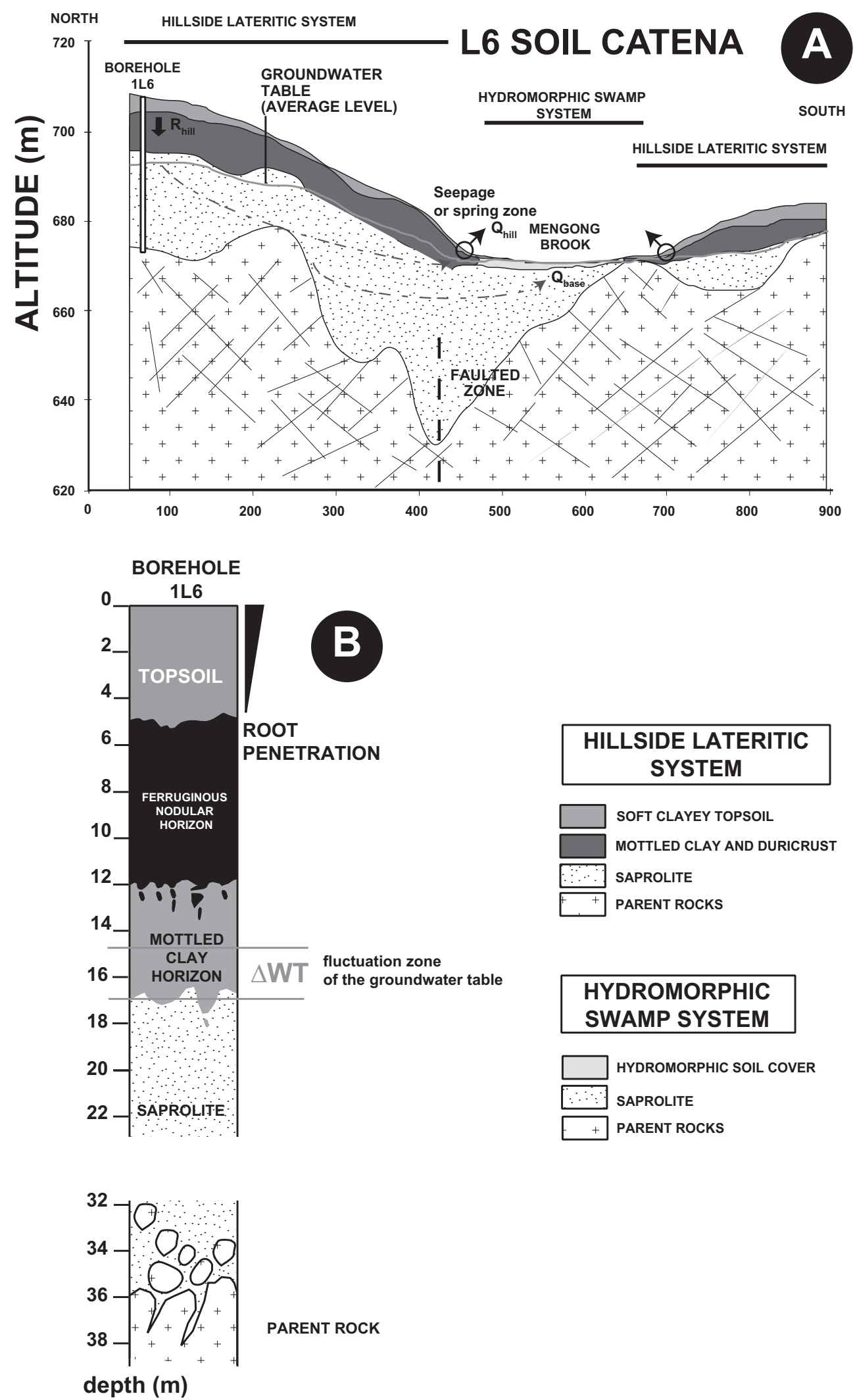

Fig. 2. (A) Cross section of the catena L6 showing the distribution of the weathered materials within both hillside and swamp systems and (B) profile 1L6 (adapted from Braun et al., 2005). The hillside recharge $R_{\text {hill }}$, the discharge $Q_{\text {hill }}$ and $Q_{\text {base }}$ are also indicated. 
pseudomorphosed by secondary clays (Fe oxides or oxihydroxides), illite and 1:1 clay minerals (e.g. kaolinite). In the upper part of the saprolite, the ferruginization process leads to iron segregation, mottling and nodules. Local glaebulization process leads to the hardening of saprolite remnants by iron oxides. The coalescence of the indurate phases leads progressively to the development of the carapace horizon due to the water table fluctuations at the expense of the mottled clay horizon. It becomes a continuous ferruginous indurate network crossed by soft bleached whitish seams, with boundaries that are coloured by iron oxides and oxyhydroxides. The carapace is assimilated to the plinthite and petroplinthite horizons defined in (USDA, 1999). Within the upper two-thirds of the slope, a nodular ferruginous horizon overlays the carapace. It is composed of iron crust relicts as indurate ferruginous boulders, nodules, and pebbles varying in size from a millimetre to a few centimetres and surrounded by a red clayey sandy matrix. Towards the foot of the slope, the thickness of this horizon decreases and progressively transforms itself into another ferruginous carapace with a vesicular network that continues downslope.

A soft clayey porous topsoil horizon overlays the diverse ferruginous horizons. The boundary between this soft clayey topsoil and the underlying layers is undulating and clear. A thin organo-mineral horizon ( $3 \mathrm{~cm}$ thick), depleted in clays and covered by a thin litter, tops the soft clayey horizon. The roots of the hillside vegetation are essentially concentrated in this topsoil, which has a depth of 5-6 m from the top of the soil catena. The faunal activity (e.g. termites and worms) is intense.

For the purpose of this study, we selected the profile 1L6 located at the sub-horizontal top of the North hillside at an altitude of $705 \mathrm{~m}$. The level compared to the Mengong brook, which flows at $678.5 \mathrm{~m}$ in altitude, is of $26.5 \mathrm{~m}$. This weathering lateritic profile is supposed to be the most evolved at the watershed scale, in other words, having kept the longest saprolite/soil history. Above the fractured bedrock, it is composed of $21 \mathrm{~m}$ of variegated saprolite (SAP), $3 \mathrm{~m}$ of mottled clay horizon $(\mathrm{MCH}), 7 \mathrm{~m}$ of iron crust (IC) and $5 \mathrm{~m}$ of topsoil (TOP).

At the hillside system scale, the groundwater flows through the fractured bedrock, the entire saprolite, and partly through the mottled clay horizon. The water table fluctuates up to one third of the latest horizon. Within the top ridge profile 1L6, the thickness of the vadose zone is limited to the first $15 \mathrm{~m}$ and the groundwater table floods the entire saprolite with a maximum water table fluctuation of about $3 \mathrm{~m}$. A part of this groundwater draining the hillside emerges at springs in the watershed head and at specific seepage points all around the hillside/swamp boundaries and then is conveyed to the stream. The mean discharge rate of the main spring (spring MEN1) was measured at $0.87 \mathrm{l} / \mathrm{s}$, which corresponds to $46 \mathrm{~mm} / \mathrm{yr}$ related to the watershed surface area. The swamp system covers $20 \%$ of the watershed. Through the water-year, the swamp is flooded and constitutes a seepage zone, the extent of which depends on the seasonal distribution of the rain.

\section{MATERIAL AND METHODOLOGY}

\subsection{Water sampling and analyses}

Water samples analysed for trace elements were collected monthly from August 1994 to January 1997 at the main spring (MEN1) and at the outlet of the Mengong brook. An additional sampling was carried out in 2011 for throughfall and litter leachates for major element analyses. Litter leachates were obtained by leaving sampling plastic bags below litter traps during rain events in May, June, July and September 2011.

The water samples were filtered on-site with cellulose acetate $0.45 \mu \mathrm{m}$ membranes using a polycarbonate Millipore filtration unit. Samples were then stored in acid washed Nalgene ${ }^{\circledR}$ polypropylene bottles, either acidified with ultrapure $15 \mathrm{~N} \mathrm{HNO}_{3}$ for major cation and trace element analyses or non-acidified for major anion analyses. Measurements of conductivity, $\mathrm{pH}$, alkalinity and water temperature were carried out on-site. Major cations $(\mathrm{Ca}$, $\mathrm{Mg}, \mathrm{K}, \mathrm{Na})$ and anions $\left(\mathrm{Cl}, \mathrm{SO}_{4}, \mathrm{NO}_{3}\right)$ were determined by Ion Chromatography at the Institut de Physique du Globe, Paris (IPGP) and Geoscience Environnement Toulouse (GET). Dissolved trace element concentrations were measured by ICP-MS (Elan 6000) at GET. Usual incertitude was $5 \%$ and detection limit up to $1 \mathrm{ng} / \mathrm{L}$ for the heaviest elements. Aqueous silica concentrations were measured both by standard colorimetry (molybdate blue method) and by ICP-MS. The international standard SLRS-3 was used as a reference.

\subsection{Sampling, analytical procedures of parental rock and regolith}

Due to the presence of the groundwater table at $15 \mathrm{~m}$ depth in 1L6, it was not possible to collect preserved saprolite samples. A mechanic auger was used to drill up to the parent rock and collect a saprolite composite sample. Parent rock samples were collected from drilling core at a depth of $36 \mathrm{~m}$ and in the streambed on track L5 (Braun et al., 2005). A handmade pit was dug up to the groundwater table to access the weathered materials.

The parent rock density was determined with a Goguel ${ }^{\circledR}$ densimeter. Bulk soil samples of about $2 \mathrm{~kg}$ were collected, each $50 \mathrm{~cm}$ from the surface towards the groundwater table. Corresponding samples were also collected in soft soap plastic boxes to preserve the soil structure. On these samples, bulk density $\left(\rho_{\mathrm{w}}\right)$ was obtained by the paraffin method and grain densities $\left(\rho_{\mathrm{g}}\right)$ by the air pycnometer method (three replicates). Porosity was calculated using the equation $\Phi=1-\left[\rho_{\mathrm{w}} / \rho_{\mathrm{g}}\right]$, where $\Phi$ is the symbol of porosity. The bulk density measurements were carried out on the bulk ferruginous nodular horizon samples. The proportion of nodules/matrix was quantified for the bulk mass balance calculation.

Thin sections of rocks and soils were observed by optical microscopy as well as by SEM coupled with EDS. Microprobe analyses of the rock forming minerals were carried out on hand picked separates with CAMECA SX50 at Lab- 
oratoire des Mécanismes de Transfert en Géologie (LMTG), Toulouse (France).

Powder samples were obtained with an automatic agate mortar. Crystalline phases in the randomly oriented samples of weathered materials were analysed by X-ray diffraction using a copper source with a Siemens XRD diffractometer at IRD, Bondy, France. The radiation lengths $\lambda$ were 1.54060 and $1.54443 \AA$. The $2 \theta$ range was $120^{\circ}$ with steps of $0.03^{\circ}$.

Major and 40 trace elements from rocks and weathered materials were analysed by ICP-AES and ICP-MS at the SARM (Centre de Recherche Petrographique et Geochimique-CNRS, Vandouvre-lès-Nancy) after $\mathrm{LiBO}_{2}$ fusion and $\mathrm{HNO}_{3}$ dissolution. The data set for major elements, Th and $\mathrm{Zr}$ in the profile 1L6 is already displayed in (Braun et al., 2005).

The detection limits (in wt.\%) are 0.8 for $\mathrm{SiO}_{2}, 0.3$ for $\mathrm{Al}_{2} \mathrm{O}_{3}, 0.1$ for $\mathrm{Fe}_{2} \mathrm{O}_{3}, 0.03$ for $\mathrm{MnO}, 0.4$ for $\mathrm{MgO}, 0.5$ for $\mathrm{CaO}, 0.08$ for $\mathrm{Na}_{2} \mathrm{O}, 0.05$ for $\mathrm{K}_{2} \mathrm{O}, 0.09$ for $\mathrm{TiO}_{2}$ and 0.2 for $\mathrm{P}_{2} \mathrm{O}_{5}$. The detection limit of the Loss on Ignition (LoI), the measure of volatile $\mathrm{H}_{2} \mathrm{O}, \mathrm{CO}_{2}, \mathrm{~F}, \mathrm{Cl}$ and $\mathrm{S}$, is found to be $0.02 \mathrm{wt} . \%$. The error for trace elements is less than $5 \%$.

\section{RESULTS}

For both parent rocks and weathered products, Table 1 displays the trace element composition along with other chemical and physical data already published (Braun et al., 2005) and included for convenience (major elements, $\mathrm{Th}, \mathrm{Zr}$, grain size fractions, bulk and grain densities). Fig. 3 presents the depth-profiles for selected elements: redox sensitive ( $\mathrm{V}, \mathrm{Cr}, \mathrm{Fe}, \mathrm{Mn}$ ), potentially immobile ( $\mathrm{Th}, \mathrm{Zr}, \mathrm{Nb}$, $\mathrm{Ti})$, potentially mobile as alkaline ( $\mathrm{Na}, \mathrm{K}, \mathrm{Rb})$, alkaline earths (Ca, Mg, Sr, Ba), REEs, Y, U, Si, Ge, Ga, Al and heavy metals $(\mathrm{Co}, \mathrm{Cu}, \mathrm{Zn}, \mathrm{Ni})$. The first striking point is the tremendous depletion in the incipient stage of the saprolitization of $\mathrm{Na} \mathrm{Ca}$, and $\mathrm{Mg}$ compared to all other elements and especially compared to the other alkaline and alkaline earth as $\mathrm{K}, \mathrm{Rb}, \mathrm{Ba}$ and $\mathrm{Sr}$. There is an enrichment trend in the in situ weathering products for $\mathrm{Ge}, \mathrm{Si}, \mathrm{Ga}, \mathrm{Al}$, $\mathrm{V}, \mathrm{Cr}, \mathrm{Fe}, \mathrm{Ta}, \mathrm{Hf}, \mathrm{Th}, \mathrm{Zr}$, U while a depletion trend for LREE, HREE, Y and Mn. For Co, Ni, $\mathrm{Cu}$ and $\mathrm{Zn}$, the trend is less obvious. A significant threshold is observed for almost all the elements between the top of the iron crust and overlying topsoil. The shift is positive for Ti, K, Si, Al, $\mathrm{Rb}, \mathrm{Sr}, \mathrm{Ba}, \mathrm{HREE}$, LREE, Y, Mn, Ta, Hf, Nb, Zr, and Sn and negative for $\mathrm{Th}, \mathrm{Fe}, \mathrm{V}, \mathrm{Cr}, \mathrm{Pb} \mathrm{Ga}, \mathrm{U}$ and $\mathrm{Ge}$.

Table 2 sums up the composition of trace elements (statistics and Volume Weight Mean, VWM) for (i) the spring water MEN1, representative of the water from the springs and seepage zones at the watershed scale, and (ii) the outlet water. Fig. 4 displays the composite bedrock normalised pattern for the Mengong spring and outlet waters. For the displayed elements the fractionation is higher in the swamp system than in the hillside system. The redox sensitive elements (except $\mathrm{Mn}$ and $\mathrm{Ce}$ ) and potential immobile elements (except Ti) are below the detection limit in the hillside system while they are present in significant amount in the swamp system. Among alkaline and alkaline earths,
$\mathrm{K}, \mathrm{Rb}, \mathrm{Sr}, \mathrm{Ba}$ are less fractionated then $\mathrm{Ca}, \mathrm{Na}$ and $\mathrm{Mg}$ in both swamp and hillside systems.

In order to compare the signatures of the different kind of waters from the Nsimi SEW (rainfall, troughfall, litter leachates, groundwater at piezometric level and weathering front, brook -MEN1 spring and outlet-), Table 3 sums up $\mathrm{pH}$, silica, major base cations, sum of base cations $(\mathrm{TZ}+)$ and $\mathrm{Cl}$ contents compiled and this study (Braun et al., 2005). In addition, the chemistry of groundwater sampled in the ridge top well P5 from the Mule Hole SEW (Violette et al., 2010) is also reported for further comparisons between both ecosystems. The respective $\mathrm{Cl}$-normalised molar ratios are also mentionned along with the seawater composition and the marine cyclic salt ratios. At Nsimi, the rainfalls collected from 1997 to 1999 are particularly diluted (TZ+ $\approx 20 \mu \mathrm{eq} / \mathrm{L}$ ) with a low average $\mathrm{Na}$ content of $4 \mu \mathrm{mol} / \mathrm{L}$ and with other base cation contents less than $5 \mu \mathrm{mol} / \mathrm{L}$. The $\mathrm{Na} / \mathrm{Cl}$ ratio $(0.93)$ is not significantly different from the seawater ratio (0.86) given the incertitude linked to these low concentrations. The Si and DOC (dissolved organic carbon) contents are below the detection limit. The throughfalls collected from 1995 to 1997 and 2011 exhibit an average $\mathrm{Na}$ contents from 2.8 to $5.1 \mu \mathrm{mol} / \mathrm{L}$, similar to the rainfalls, whilst the other major cations $(\mathrm{Ca}, \mathrm{Mg}, \mathrm{K})$ are in higher concentrations ( $\mathrm{TZ}+$ from 128 to $380 \mu \mathrm{eq} / \mathrm{L}$ ) dominated by $\mathrm{K}$ with contents from 38 to $168 \mu \mathrm{mol} / \mathrm{L}$. The elevated $\mathrm{K}$ contents are associated with high $\mathrm{Cl}$ contents (up to $40 \mu \mathrm{mol} / \mathrm{L}$ ) leading to $\mathrm{Na} / \mathrm{Cl}$ ratio below the marine ratio $(0.07-0.65)$. In the throughfall the average Si contents are low $(17 \mu \mathrm{mol} / \mathrm{L})$ and the DOC contents range between 2.7 and $7.1 \mathrm{mg} / \mathrm{L}$. The waters collected below the litter traps in 2011 exhibit the highest base cation concentrations of the sampled pools with $\mathrm{TZ}+$ of $2030 \mu \mathrm{eq} / \mathrm{L}$. The average $\mathrm{Na}$ content is low $(11 \mu \mathrm{mol} / \mathrm{L})$ but twice those of rainfalls, certainly due to moderate evaporation processes. With a concentration of $513 \mu \mathrm{mol} / \mathrm{L}, \mathrm{K}$ is the dominant cation associated with high $\mathrm{Mg}$ and $\mathrm{Ca}$ contents $(345 \mu \mathrm{mol} / \mathrm{L}$ and $405 \mu \mathrm{mol} / \mathrm{L}$, respectively). The $\mathrm{Cl}$ content is similar to those of the 2011's troughfall sampling with $39 \mu \mathrm{mol} / \mathrm{L}$, leading to a $\mathrm{Na} / \mathrm{Cl}$ ratio of 0.28 . Both $\mathrm{Si}$ and DOC contents are significantly high with $347 \mu \mathrm{mol} /$ $\mathrm{L}$ and $71 \mathrm{mg} / \mathrm{L}$, respectively. The chemistry of throughfalls and litter leachates indicates that $\mathrm{K}, \mathrm{Ca}, \mathrm{Mg}, \mathrm{Si}$ and $\mathrm{Cl}$ are significantly cycled by the vegetation at the seasonnal scale. The hillside groundwater shows a positive concentration gradient in terms of major base cations and protons from the topmost part of the water table $(\mathrm{TZ}+\approx 90 \mu \mathrm{eq} / \mathrm{L}$; $\mathrm{pH} \approx 5.0$ ) towards the bedrock/saprolite weathering front $(\mathrm{TZ}+\approx 400 \mu \mathrm{eq} / \mathrm{L} ; \mathrm{pH} \approx 6.0$ ). The topmost groundwater is saturated with respect to quartz and kaolinite with $\mathrm{Si}$ content of $100 \mu \mathrm{mol} / \mathrm{L}$ and it is extremely diluted in $\mathrm{Na}$, $\mathrm{Ca}, \mathrm{Mg}$ and $\mathrm{K}$. At the weathering front the $\mathrm{Na}$ and $\mathrm{Si}$ contents increase significantly to $250 \mu \mathrm{mol} / \mathrm{L}$ and to $280 \mu \mathrm{mol} /$ $\mathrm{L}$, respectively. The $\mathrm{Cl}, \mathrm{Ca}, \mathrm{Mg}$ and $\mathrm{K}$ contents are in the same range at the top ridge piezometric level and at the weathering front. The water at the weathering front from Nsimi remains significantly diluted $(400 \mu \mathrm{eq} / \mathrm{L})$ compared to that from Mule Hole $(6815 \mu \mathrm{eq} / \mathrm{L})$ (Violette et al., 2010). It has to be noticed that the entire hillside groundwater is DOC free (DOC $<1 \mathrm{mg} / \mathrm{L}$, detection limit). 


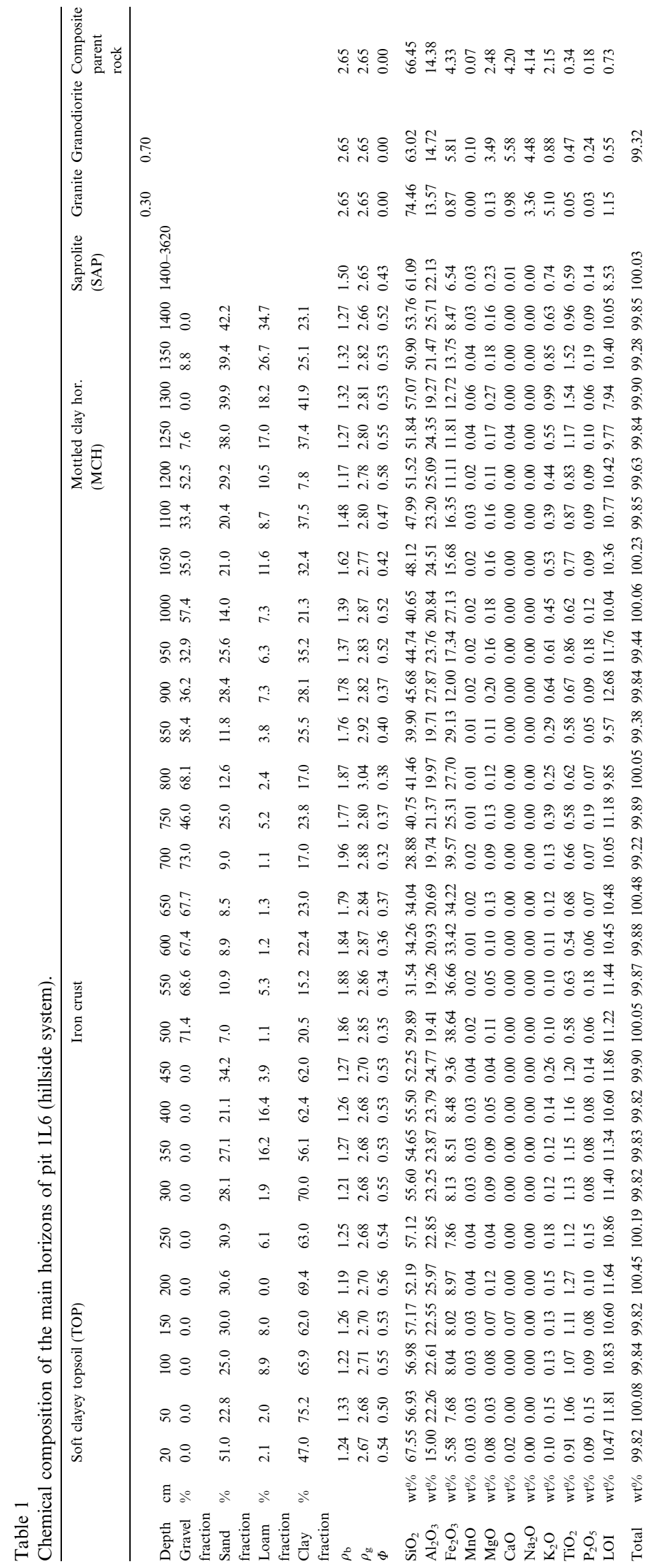

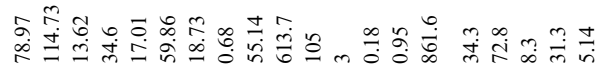

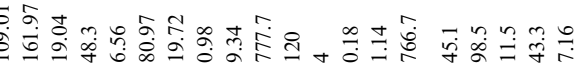

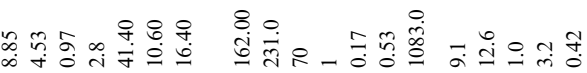

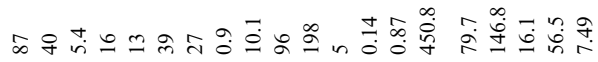

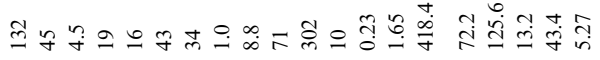

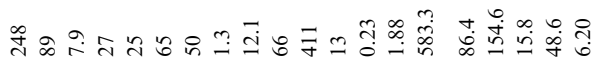

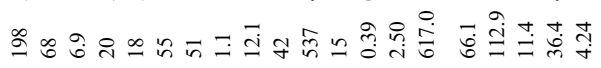

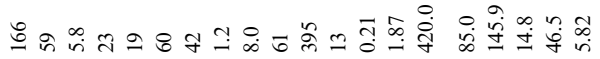

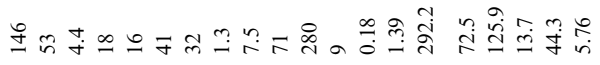

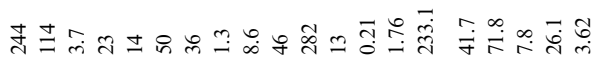

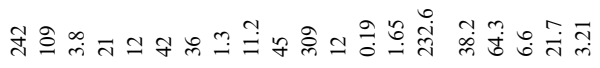

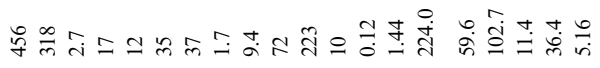

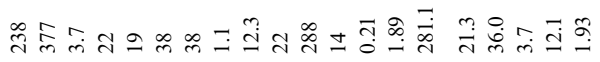

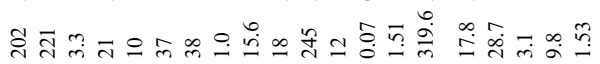

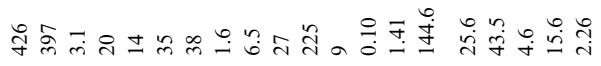

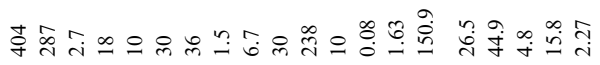

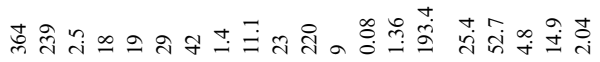

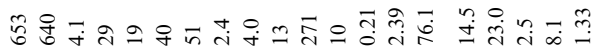

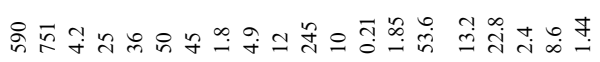

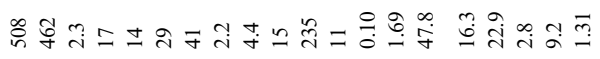

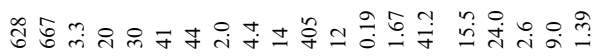

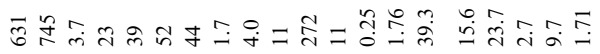

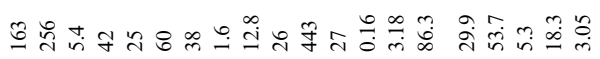

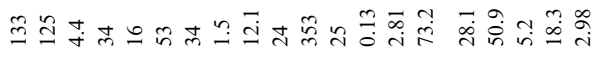

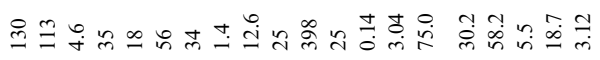

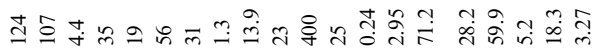

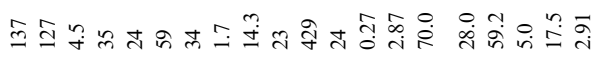

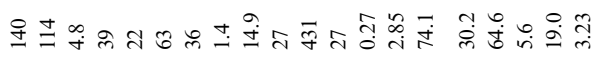

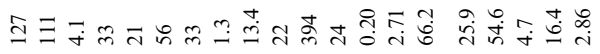

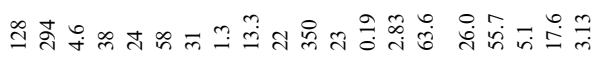

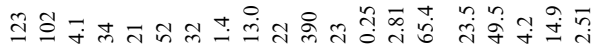

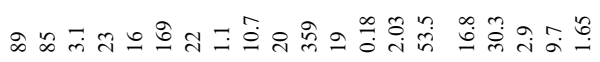

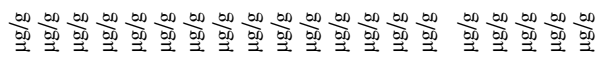

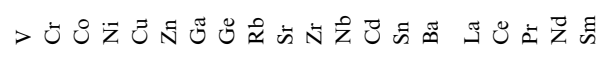




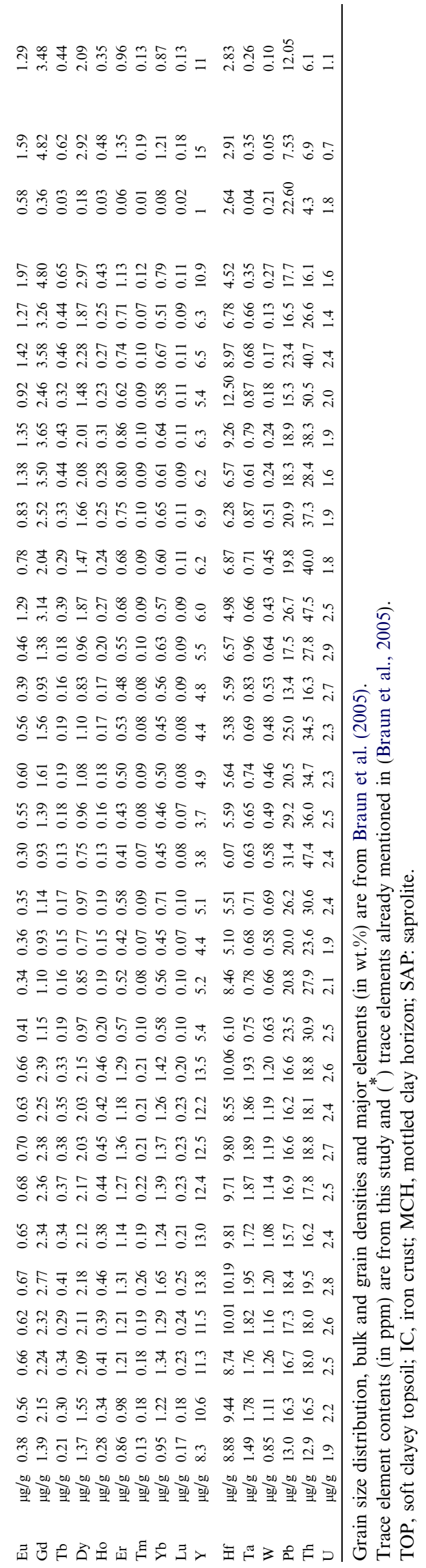

\section{DISCUSSION}

The first section of the discussion will address the elemental distribution within the constitutive minerals of both parent rocks and weathering products, which is an indispensable preamble to trace the origin of the long-term and contemporary chemical weathering fluxes. The second section will focus on the quantification of the solid-state elemental and mineralogical changes within in situ weathered materials and topsoil using appropriate immobile element and parental references. The third section will deal with the origin and the quantification of the contemporary elemental fluxes and the saprolite production rate. Comparisons will be carried out in terms of both hydrological regime and aggressiveness of the pore water with a ridge top immature weathering profile from Mule Hole SEW, South India. We will finally merge both long-term transformation and contemporary chemical fluxes within the Nsimi SEW profile to infer the long-term trajectory of the lateritic tropical terrain of South Cameroon.

\subsection{Elemental distribution in bedrock and weathering products}

The modal abundances presented in (Braun et al., 2005) for both parent rock end members (granodiorite and granite) and weathering products were refined following the method proposed in (Braun et al., 2009) to better appraise the elemental contribution of the constitutive minerals and errors. In the parent rocks, assuming that apatite controls $100 \%$ of $\mathrm{P}_{2} \mathrm{O}_{5}$, its modal abundance is first determined; then the proportion of $\mathrm{Ca}$ linked to apatite is deducted from the bulk analysis. To estimate the modal abundances with the apatite-corrected bulk analysis, we apply a linear inverse method using least squares criterion (Tarantola and Valette, 1982). The solution and error is given by Eqs. (47) and (48) in (Tarantola and Valette, 1982):

$$
\begin{aligned}
& \hat{x}=\left(A^{T} \cdot C_{y_{o} y_{o}}^{-1} \cdot A\right)^{-1} \cdot A^{T} \cdot C_{y_{o} y_{o}}^{-1} \cdot y_{o} \\
& C_{\hat{x} \hat{x}}=\left(A^{T} \cdot C_{y_{o} y_{o}}^{-1} \cdot A\right)^{-1}
\end{aligned}
$$

where $y_{0}$ is the chemical composition vector of the rock, $A$ is the matrix of the main mineral compositions and $\hat{x}$ the $a$ posteriori solution (modal abundance vector), $C_{y_{0} y_{0}}^{-1}$ is the inverse of the covariance matrix and $C_{\hat{x} \hat{x}}$ is the a posteriori error covariance of the solution. The residuals are calculated by $y_{0}-\hat{y}$, where $\hat{y}=A . \hat{x}$. The minerals selected in the matrix $A$ are quartz, biotite, K-feldspar, oligoclase, hornblende, magnetite, epidote for the graniodiorite and quartz, biotite, K-feldspar, albite, titanomagnetite and épidote for the granite. Both bulk compositions $(+/-\sigma)$, calculated modal abundances and their errors, estimated bulk compositions $(\hat{y})$ and associated residuals, and the estimated contributions from each mineral to the whole rock are summed up in Table 4 for the parent rock end members and the composite rock and in Table 5 for the weathering products.

In the composite parent rock, the distribution of major elements in the primary minerals is, in decreasing order: 

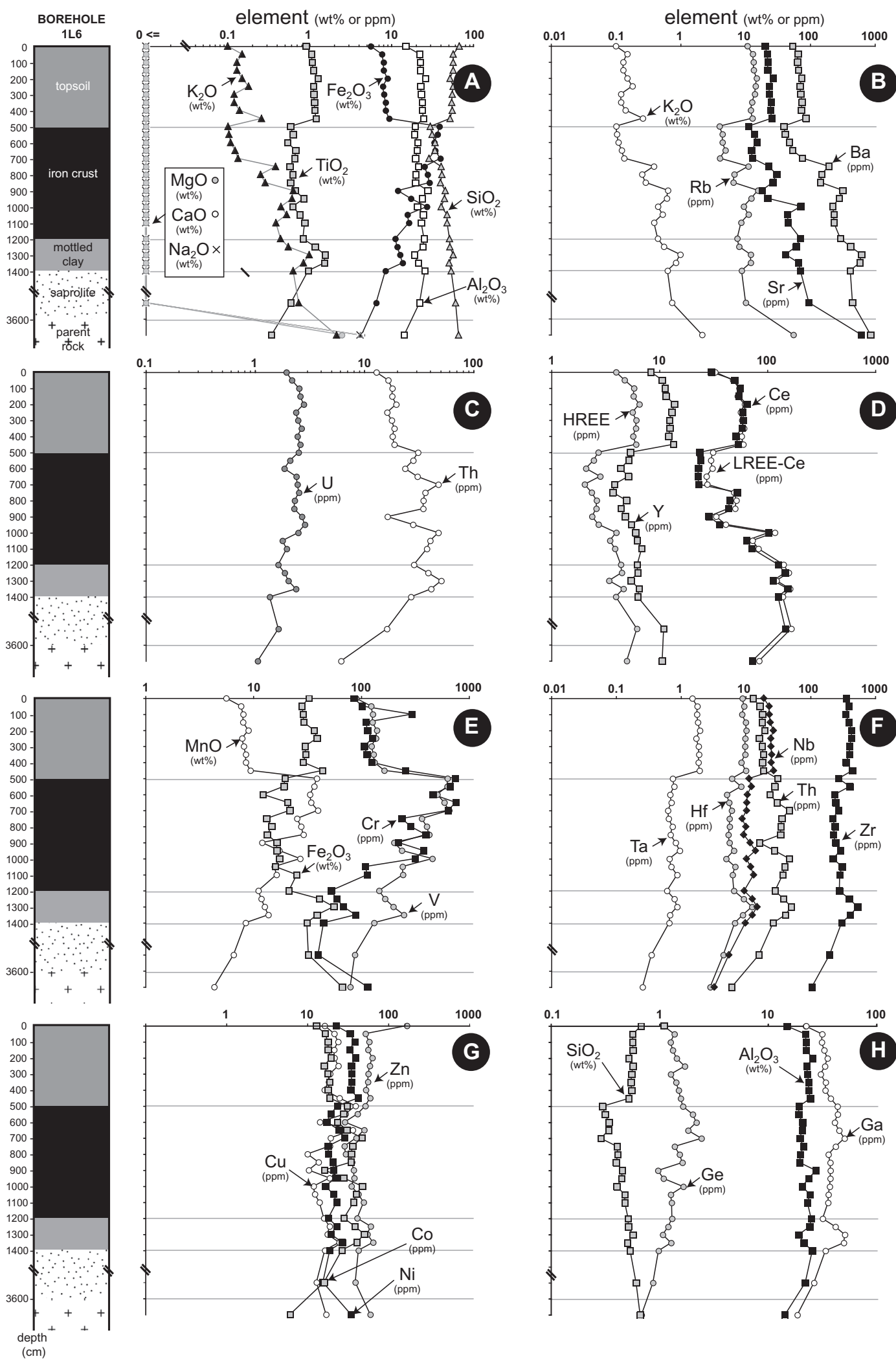

Fig. 3. (A-H) Depth profiles of major elements (in wt.\%) and trace elements (in ppm) in the profile 1L6. 
Table 2

Statistics of the composition in trace elements and Volume Weight Mean (VWM) for (i) the MEN1 spring waters and (ii) the outlet waters from the Mengong brook, Nsimi SEW.

\begin{tabular}{|c|c|c|c|c|c|c|c|c|c|c|c|}
\hline & & $\begin{array}{l}\text { Spring } \\
\text { average } \\
n=23\end{array}$ & $\pm 1 \sigma$ & Min & Max & VWM & $\begin{array}{l}\text { Outlet } \\
\text { average } \\
n=27\end{array}$ & $\pm 1 \sigma$ & Min & Max & VWM \\
\hline $\mathrm{Rb}$ & $\mu \mathrm{mol} / \mathrm{L}$ & 0.004 & 0.001 & 0.001 & 0.005 & 0.003 & 0.009 & 0.007 & 0.003 & 0.028 & 0.009 \\
\hline $\mathrm{Sr}$ & $\mu \mathrm{mol} / \mathrm{L}$ & 0.065 & 0.009 & 0.029 & 0.074 & 0.064 & 0.216 & 0.045 & 0.095 & 0.284 & 0.205 \\
\hline $\mathrm{Ba}$ & $\mu \mathrm{mol} / \mathrm{L}$ & 0.084 & 0.016 & 0.033 & 0.116 & 0.084 & 0.172 & 0.066 & 0.074 & 0.425 & 0.178 \\
\hline $\mathrm{Al}$ & $\mu \mathrm{mol} / \mathrm{L}$ & 0.706 & 0.434 & 0.139 & 1.589 & 0.569 & 11.633 & 4.214 & 4.918 & 18.658 & 11.726 \\
\hline $\mathrm{Ga}$ & $\mu \mathrm{mol} / \mathrm{L}$ & 0.005 & 0.001 & 0.002 & 0.006 & 0.005 & 0.009 & 0.004 & 0.001 & 0.024 & 0.010 \\
\hline $\operatorname{Si}\left(^{*}\right)$ & $\mu \mathrm{mol} / \mathrm{L}$ & 92 & 10 & 67 & 111 & 91 & 128 & 14 & 94 & 146 & 129 \\
\hline $\operatorname{Ti}\left({ }^{*}\right)$ & $\mu \mathrm{mol} / \mathrm{L}$ & 0.006 & 0.005 & $<\mathrm{DL}$ & 0.019 & 0.006 & 0.041 & 0.038 & 0.009 & 0.158 & 0.039 \\
\hline $\operatorname{Zr}\left({ }^{*}\right)$ & $\mu \mathrm{mol} / \mathrm{L}$ & $<\mathrm{DL}$ & & $<\mathrm{DL}$ & $<\mathrm{DL}$ & $<\mathrm{DL}$ & 0.004662 & 0.002054 & 0.000853 & 0.007908 & 0.003813 \\
\hline $\mathrm{Hf}$ & $\mu \mathrm{mol} / \mathrm{L}$ & $<\mathrm{DL}$ & & $<\mathrm{DL}$ & $<\mathrm{DL}$ & $<\mathrm{DL}$ & 0.000077 & 0.000034 & 0.000013 & 0.000141 & 0.000060 \\
\hline $\mathrm{Nb}$ & $\mu \mathrm{mol} / \mathrm{L}$ & $<\mathrm{DL}$ & & $<\mathrm{DL}$ & $<\mathrm{DL}$ & $<\mathrm{DL}$ & 0.000060 & 0.000047 & 0.000007 & 0.000173 & 0.000092 \\
\hline V & $\mu \mathrm{mol} / \mathrm{L}$ & $<\mathrm{DL}$ & & $<\mathrm{DL}$ & $<\mathrm{DL}$ & $<\mathrm{DL}$ & 0.028 & 0.014 & 0.008 & 0.065 & 0.025 \\
\hline $\mathrm{Cr}$ & $\mu \mathrm{mol} / \mathrm{L}$ & $<\mathrm{DL}$ & & $<\mathrm{DL}$ & $<\mathrm{DL}$ & $<\mathrm{DL}$ & 0.037 & 0.007 & 0.026 & 0.055 & 0.034 \\
\hline $\mathrm{Mn}$ & $\mu \mathrm{mol} / \mathrm{L}$ & 0.087 & 0.022 & 0.025 & 0.117 & 0.085 & 0.235 & 0.140 & 0.014 & 0.596 & 0.217 \\
\hline $\mathrm{Fe}$ & $\mu \mathrm{mol} / \mathrm{L}$ & $<\mathrm{DL}$ & & $<\mathrm{DL}$ & $<\mathrm{DL}$ & $<\mathrm{DL}$ & 6.747 & 2.539 & 2.862 & 11.015 & 6.728 \\
\hline Co & $\mu \mathrm{mol} / \mathrm{L}$ & 0.003 & 0.001 & 0.001 & 0.005 & 0.003 & 0.005 & 0.002 & 0.001 & 0.010 & 0.005 \\
\hline $\mathrm{Ni}$ & $\mu \mathrm{mol} / \mathrm{L}$ & 0.011 & 0.011 & 0.004 & 0.060 & 0.011 & 0.030 & 0.021 & 0.007 & 0.094 & 0.028 \\
\hline $\mathrm{Cu}$ & $\mu \mathrm{mol} / \mathrm{L}$ & 0.004 & 0.005 & $<\mathrm{DL}$ & 0.021 & 0.004 & 0.017 & 0.007 & 0.003 & 0.028 & 0.015 \\
\hline $\mathrm{Zn}$ & $\mu \mathrm{mol} / \mathrm{L}$ & 0.035 & 0.019 & $<\mathrm{DL}$ & 0.068 & 0.027 & 0.094 & 0.079 & 0.016 & 0.274 & 0.057 \\
\hline $\mathrm{La}$ & $\mu \mathrm{mol} / \mathrm{L}$ & 0.000628 & 0.000486 & 0.000099 & 0.002290 & 0.000536 & 0.001909 & 0.000711 & 0.000551 & 0.003339 & 0.002018 \\
\hline $\mathrm{Ce}$ & $\mu \mathrm{mol} / \mathrm{L}$ & 0.000822 & 0.000484 & 0.000122 & 0.001616 & 0.000723 & 0.004392 & 0.001566 & 0.001314 & 0.006943 & 0.004594 \\
\hline $\operatorname{Pr}$ & $\mu \mathrm{mol} / \mathrm{L}$ & 0.000104 & 0.000058 & 0.000018 & 0.000212 & 0.000092 & 0.000515 & 0.000181 & 0.000171 & 0.000837 & 0.000531 \\
\hline $\mathrm{Nd}$ & $\mu \mathrm{mol} / \mathrm{L}$ & 0.000406 & 0.000230 & 0.000029 & 0.000956 & 0.000343 & 0.002052 & 0.000690 & 0.000737 & 0.003121 & 0.002105 \\
\hline $\mathrm{Sm}$ & $\mu \mathrm{mol} / \mathrm{L}$ & 0.000079 & 0.000048 & $<\mathrm{DL}$ & 0.000175 & 0.000086 & 0.000442 & 0.000183 & 0.000059 & 0.000796 & 0.000422 \\
\hline $\mathrm{Eu}$ & $\mu \mathrm{mol} / \mathrm{L}$ & 0.000012 & 0.000016 & $<\mathrm{DL}$ & 0.000042 & 0.000007 & 0.000091 & 0.000042 & 0.000033 & 0.000178 & 0.000092 \\
\hline $\mathrm{Gd}$ & $\mu \mathrm{mol} / \mathrm{L}$ & 0.000044 & 0.000048 & $<\mathrm{DL}$ & 0.000143 & 0.000033 & 0.000300 & 0.000122 & 0.000097 & 0.000550 & 0.000304 \\
\hline $\mathrm{Tb}$ & $\mu \mathrm{mol} / \mathrm{L}$ & 0.000003 & 0.000006 & $<\mathrm{DL}$ & 0.000026 & 0.000001 & 0.000042 & 0.000018 & 0.000012 & 0.000070 & 0.000040 \\
\hline Dy & $\mu \mathrm{mol} / \mathrm{L}$ & 0.000020 & 0.000033 & $<\mathrm{DL}$ & 0.000104 & 0.000008 & 0.000256 & 0.000081 & 0.000106 & 0.000411 & 0.000266 \\
\hline Ho & $\mu \mathrm{mol} / \mathrm{L}$ & $<\mathrm{DL}$ & & $<\mathrm{DL}$ & $<\mathrm{DL}$ & $<\mathrm{DL}$ & 0.000048 & 0.000014 & 0.000017 & 0.000073 & 0.000048 \\
\hline $\mathrm{Er}$ & $\mu \mathrm{mol} / \mathrm{L}$ & $<\mathrm{DL}$ & & $<\mathrm{DL}$ & $<\mathrm{DL}$ & $<\mathrm{DL}$ & 0.000131 & 0.000046 & 0.000061 & 0.000233 & 0.000135 \\
\hline $\mathrm{Tm}$ & $\mu \mathrm{mol} / \mathrm{L}$ & $<\mathrm{DL}$ & & $<\mathrm{DL}$ & $<\mathrm{DL}$ & $<\mathrm{DL}$ & 0.000017 & 0.000008 & 0.000006 & 0.000031 & 0.000012 \\
\hline $\mathrm{Yb}$ & $\mu \mathrm{mol} / \mathrm{L}$ & 0.000003 & 0.000007 & $<\mathrm{DL}$ & 0.000030 & 0.000004 & 0.000128 & 0.000044 & 0.000045 & 0.000193 & 0.000127 \\
\hline $\mathrm{Lu}$ & $\mu \mathrm{mol} / \mathrm{L}$ & $<\mathrm{DL}$ & & $<\mathrm{DL}$ & $<\mathrm{DL}$ & $<\mathrm{DL}$ & 0.000018 & 0.000006 & 0.000009 & 0.000029 & 0.000015 \\
\hline Y & $\mu \mathrm{mol} / \mathrm{L}$ & 0.000560 & 0.000337 & 0.000088 & 0.001178 & 0.000459 & 0.002492 & 0.000800 & 0.000766 & 0.004077 & 0.002615 \\
\hline $\operatorname{Th}\left({ }^{*}\right)$ & $\mu \mathrm{mol} / \mathrm{L}$ & $<\mathrm{DL}$ & & $<\mathrm{DL}$ & $<\mathrm{DL}$ & $<\mathrm{DL}$ & 0.00044 & 0.00016 & 0.00011 & 0.00071 & 0.000437 \\
\hline $\mathrm{U}$ & $\mu \mathrm{mol} / \mathrm{L}$ & $<\mathrm{DL}$ & & $<\mathrm{DL}$ & $<\mathrm{DL}$ & $<\mathrm{DL}$ & 0.00007 & 0.00002 & 0.00003 & 0.00013 & 0.000069 \\
\hline
\end{tabular}

Data from Braun et al. (2005) $\left(^{*}\right)$.

- For Si: quartz $(36 \%)$, oligoclase $(31 \%)$, hornblende $(13 \%), \mathrm{K}$-feldspar $(9 \%)$, albite $(8 \%)$, epidote $(3 \%)$ and biotite $(2 \%)$.

- For Na: oligoclase (64\%), albite (29\%), hornblende $(6 \%)$ and K-feldspar (1\%).

- For K: K-feldspar (50\%), hornblende (24\%), biotite $(16 \%)$, oligoclase $(10 \%)$ and albite $(0.2 \%)$.

- For Ca: epidote $(36 \%)$, hornblende $(31 \%)$, oligoclase $(24 \%)$, albite $(6 \%)$, apatite $(4 \%)$ and biotite $(0.3 \%)$.

- For Mg: hornblende $(66 \%)$ and biotite $(34 \%)$.

From XRD patterns and thin section SEM observations of the weathered materials, the residual mineral phases are quartz $\left(\mathrm{SiO}_{2}\right)$ and zircon $\left(\mathrm{ZrSiO}_{4}\right)$. The secondary mineral assemblage is composed of clays (goethite, haematite, anatase) and clay minerals (illite, kaolinite). Gibbsite is absent on the bulk XRD patterns meaning that, if present, the content are less than $5 \%$. To assess the repartition of elements in the weathered materials, the mineral compositions used in the matrix for the linear inverse method come from the Mineralogy Database website (http://webmineral.com/ ). The quartz proportion in the composite bedrock is $24 \%$, which accounts for $38 \%$ of the $\mathrm{Si}$ content. In the in situ weathered materials, the proportion significantly increases up to $32.8 \%(53.7 \%$ of $\mathrm{Si})$ in the saprolite and then decreases to $23.1 \%(43.6 \%$ of $\mathrm{Si})$ in the mottled clay and to $12.4 \%(31.6 \%$ of $\mathrm{Si})$ in the iron crust, respectively. In the topsoil, the quartz proportion is $24.4 \%$ accounting for $44 \%$ of the $\mathrm{Si}$ content. The zircon proportion in the composite bedrock is $180 \mathrm{mg} / \mathrm{kg}$ and accounts for $100 \%$ of $\mathrm{Zr}$ 


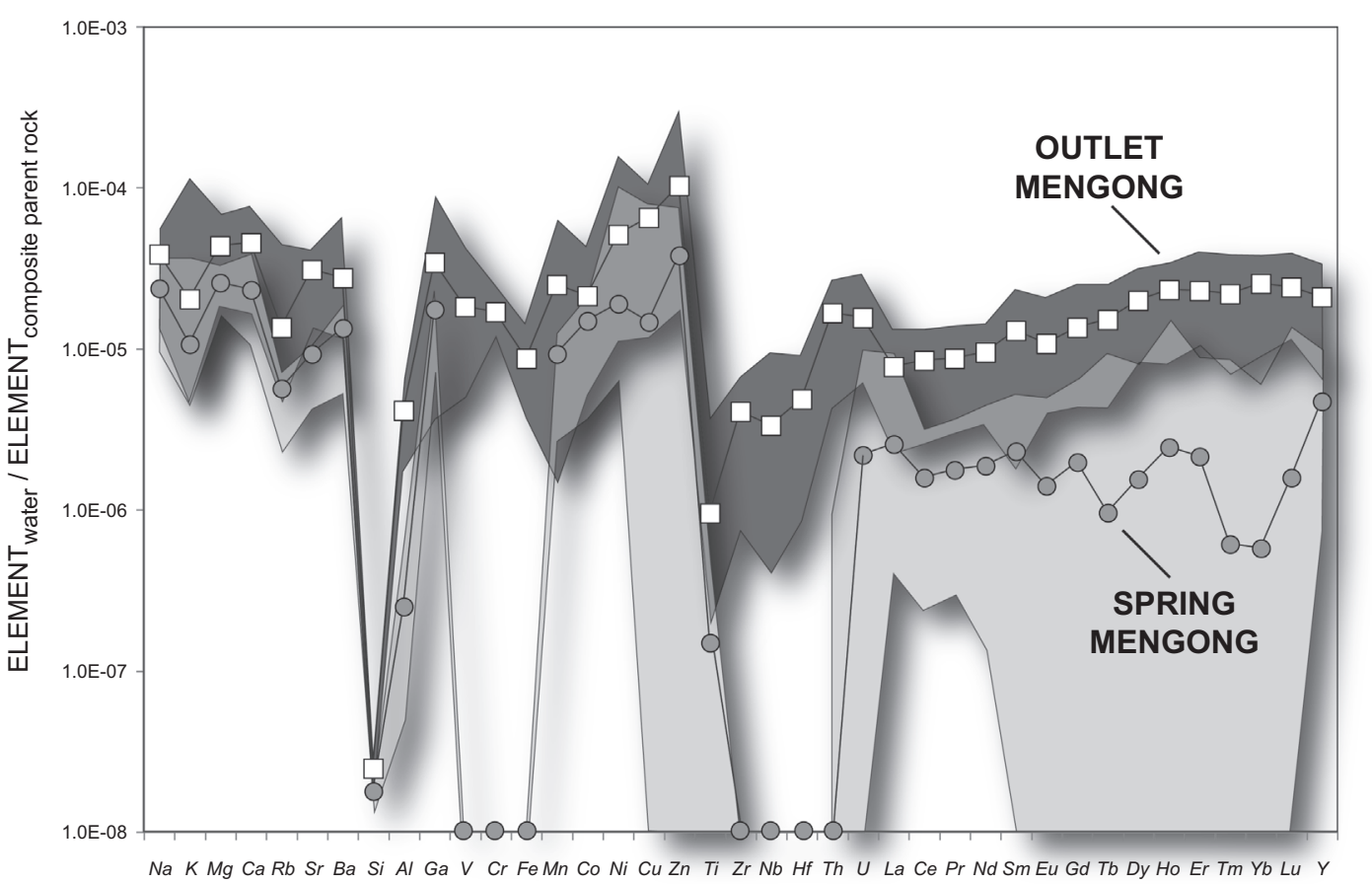

Fig. 4. Parent rock normalised patterns for the water at the Mengong outlet (white squares and dark gray shade) and for the water at the spring MEN1 (dark circles and light grey shade). The shaded areas represent the standard deviation to the mean for the waters.

based on the fact that the $\mathrm{Zr}$ content is only attributed to zircon crystals. Zircon grains are significantly accumulated in the saprolite $(480 \mathrm{mg} / \mathrm{kg})$, the mottled clay $(890 \mathrm{mg} / \mathrm{kg})$, the iron crust $(620 \mathrm{mg} / \mathrm{kg})$ and the topsoil $(920 \mathrm{mg} / \mathrm{kg})$. With amounts from $50 \%$ to $60 \%$, kaolinite $\left(\mathrm{Al}_{2} \mathrm{Si}_{2} \mathrm{O}_{5}(\mathrm{OH})_{4}\right)$ is the most abundant mineral in the weathered materials and accounts for $38-64 \%$ of the $\mathrm{SiO}_{2}$ content and for 92 $98 \%$ of the $\mathrm{Al}_{2} \mathrm{O}_{3}$ content. The proportion of iron oxides and oxihydroxides, only assessed with goethite $(\mathrm{FeOOH})$ in the mineral matrix, is low in the saprolite $(6.5 \%)$ and reaches its maximum in the iron crust $(29.4 \%)$. Goethite accounts for more than $98 \%$ of $\mathrm{Fe}$ of the weathered materials. Illite $\left(\mathrm{K}_{0.6}\left(\mathrm{H}_{3} \mathrm{O}\right)_{0.4} \mathrm{Al}_{1.3} \mathrm{Mg}_{0.3} \mathrm{Fe}^{2+}{ }_{0.1} \mathrm{Si}_{3.5} \mathrm{O}_{10}(\mathrm{OH})_{2} \cdot\left(\mathrm{H}_{2} \mathrm{O}\right)\right)$ could only be detected on the XRD patterns of saprolite and mottled clay samples. However the proportions were assessed in all the weathered horizons assuming that illite accounts for $100 \%$ of the $\mathrm{K}$ content in the weathered materials. The saprolite and mottled clay contain $9.5 \%$ and $8.9 \%$ of illite, respectively. The proportions decrease in the iron crust with $4.1 \%$ and in the topsoil with $2.2 \%$. The Ti contents are attributed to the presence of anatase in the weathered materials, whose estimated proportions tend to increase in the mottled clay $(1.2 \%)$, the iron crust $(0.7 \%)$ and the topsoil $(1.1 \%)$ compared to the saprolite $(0.6 \%)$.

\subsection{Long-term elemental fluxes in the weathering lateritic profile}

The mass balance equation set is based on the principle of mass conservation (Brimhall et al., 1991; Oh and Richter, 2005). For a chemical element $j$ :

$\frac{V_{w} \rho_{w} C_{j, w}}{100}=\frac{V_{p} \rho_{p} C_{j, p}}{100}+m_{j, \text { flux }}$ where the subscripts $p$ and $w$ refer to the parent and weathered materials, respectively. $V$ is volume in $\mathrm{cm}^{3}, \rho$ is bulk density in $\mathrm{g} / \mathrm{cm}^{3}$ and $C_{j}$ is chemical concentration of any element $j$ in weight percent (wt.\%). The $m_{j, \text { flux }}$ represents the mass of an element $j$ moving in or out of the system. The $m_{j \text {,flux }}$ is positive if the element $j$ is accumulated in the system and negative if $j$ is leached from the system.

The volumetric strain $(\varepsilon)$ or volume change is calculated from the density ratios $\rho$ and conservative element concentrations $C_{i}$ in the regolith by:

$\varepsilon_{i, w}=\frac{\rho_{p} C_{i, p}}{\rho_{w} C_{i, w}}-1$

Positive values of $\varepsilon_{i, w}$ indicate expansion, negative ones indicate collapse and values around zero, isovolumic weathering.

The addition or subtraction of a chemical element $j$, either by solute migration or mechanical translocation, is quantified by the open-system mass fraction transport function $\left(\tau_{j, w}\right)$ :

$\tau_{j, w}=\left(\frac{\rho_{w} C_{j, w}}{\rho_{p} C_{j, p}}\right)\left(\varepsilon_{i, w}+1\right)-1$

Because the calculation of $\tau_{j, w}$ takes into account both residual enrichment and deformation, a positive value for $\tau_{j, w}$ reflects a true mass gain in element $j$ of the weathered rock compared to the parent rock and a negative value indicates a mass loss. If $\tau_{j, w}=0$, the element is immobile during weathering with respect to the volume of regolith considered. Moreover, quantification of the overall mass transfers during both saprolitization and soil processes can be approached by the estimation of the chemical component 
J.-J. Braun et al. / Geochimica et Cosmochimica Acta 99 (2012) 243-270

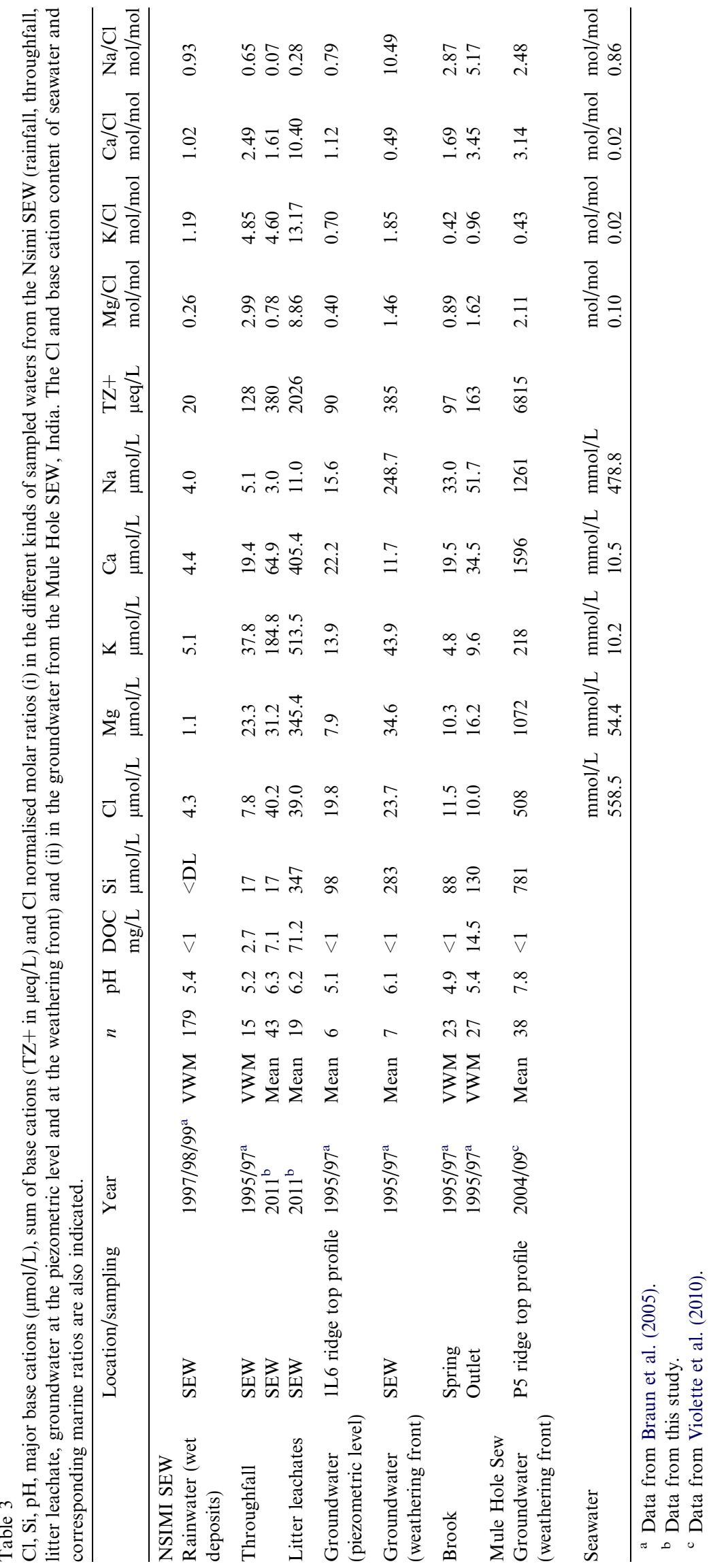




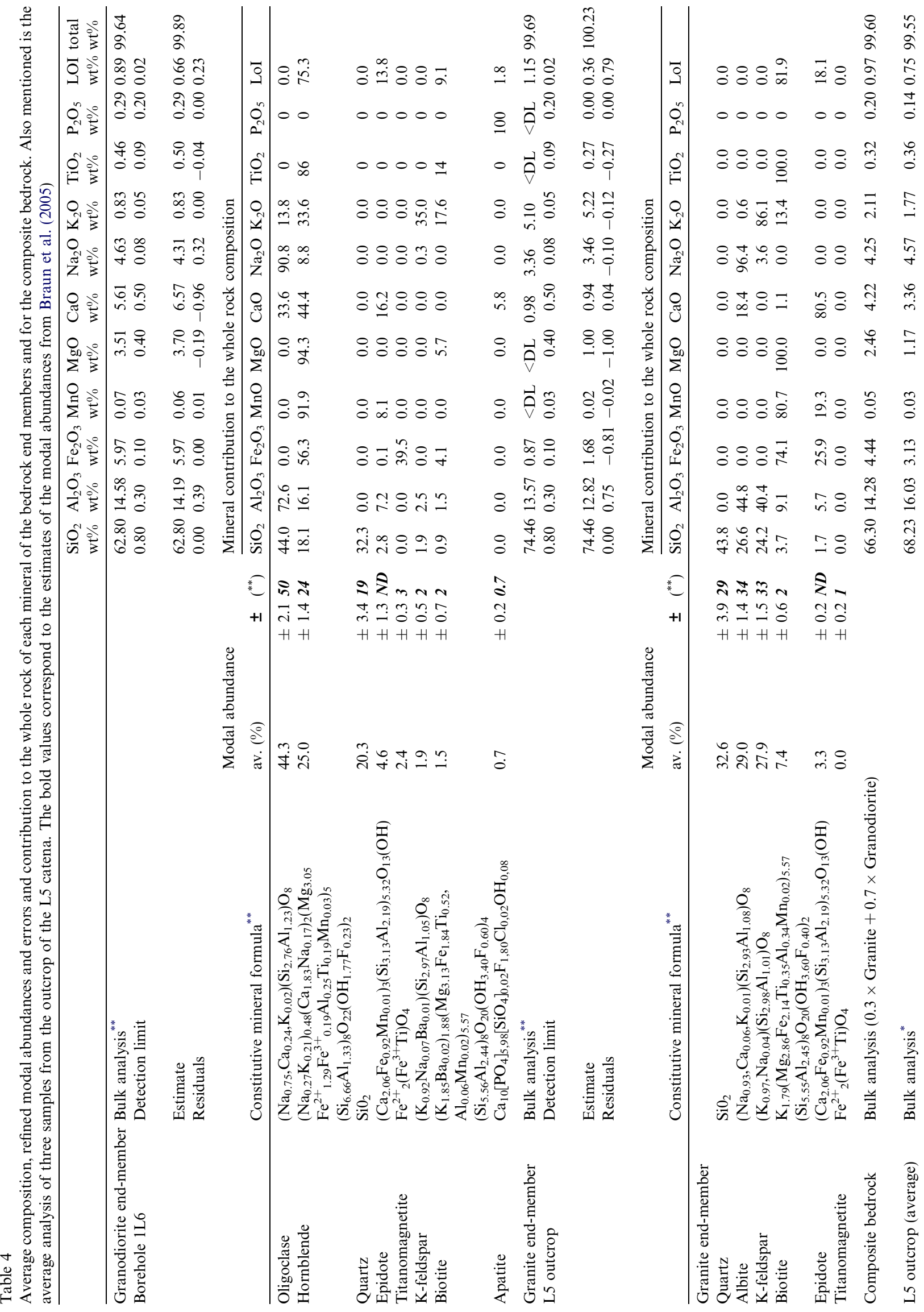


transfer. The total mass of any mobile element $j\left(\Delta M_{j}\right)$ transferred through the weathering system with thickness $z(\mathrm{~cm})$, expressed in $\mathrm{mol} / \mathrm{ha}$, is given by:

$\Delta M_{j}(\mathrm{~mol} / \mathrm{ha})=10^{6} \rho_{p} C_{j, p} \int_{0}^{z} \tau_{j, w} d Z$

Mass balance requires precise verifications regarding the determination of the parent material composition prior to the chemical weathering onset and the choice of an inert element, which should be very insoluble and resistant to weathering dissolution loss. The calculations were carried out (i) with the composite parent rock as reference $(70 \%$ of granodiorite and $30 \%$ of granite, see estimate in (Braun et al., 2005)) for the average compositions of the overlying horizons including topsoil and (ii) with the iron crust as reference of the parental material for the topsoil samples. Then, the elements can be sorted out according to their mass transfer profiles: immobile, depletion, depletion-enrichment, addition and biogenic profiles (Brantley et al., 2007; Brantley and Lebedeva, 2011).

\subsubsection{Selection of the inert element, bulk density of the saprolite and strain in the weathering profile}

The extremely low $\mathrm{Zr}$ contents in the hillside groundwater, always below the ICPMS detection limit ( 3 pmol/ L), suggest that (i) the zircon grains are stable in the weathering lateritic profile and (ii) their current behaviour is strictly inert during saprolitization and ferralitization (Braun et al., 2005; Delattre et al., 2007). These findings could justify the use of $\mathrm{Zr}$ as inert element for iso-element mass balance calculations in the hillside lateritic weathering profile only. However, due to heterogeneity in the distribution of zircon grains at the sample scale in the in situ weathering layers, an average composition for each horizon is used for the mass balance calculation. For instance the variegated saprolite composition is an average of the composition of six samples sampled by drilling between 1500 and $2420 \mathrm{~cm}$ in depth.

The mass balance calculation for the saprolite requires estimating its average bulk density. One way to estimate the average saprolite bulk density is to assume its isovolumetric weathering. If so, $\varepsilon_{\mathrm{Zr}, \mathrm{w}}$ equals to 0 and then $\rho_{\text {sapro- }}$ lite $=\rho_{p}\left(C_{\mathrm{Zr} \text {,parent }} / C_{\mathrm{Zr} \text {,saprolite }}\right)$. The calculated average bulk density of the saprolite is $1.61 \mathrm{~g} / \mathrm{cm}^{3}$.

The depth profile of the volume strain factor $\varepsilon_{\mathrm{Zr}, \mathrm{w}}$, indicates an average collapse of $35 \%$ and $33 \%$ in the mottled clay and iron crust, respectively. This collapse increases in the topsoil to $43 \%$.

The other highly charged transition elements, potentially inert, include $\mathrm{Ti}, \mathrm{Hf}$, $\mathrm{Th}$ and $\mathrm{Nb}$ (see references in (Braun et al., 1998; Brantley and White, 2009). Fig. 5 displays the $\tau_{j, \mathrm{w}}$ for these elements compared to $\varepsilon_{\mathrm{Zr}, \mathrm{w}}$. The behaviour of $\mathrm{Hf}$ rather matches that of $\mathrm{Zr}$, both elements being mainly associated in zircon crystals in granitoids. Ti exhibits a moderate depletion profile with losses reaching $20 \%$. Nb and Th have an erratic behaviour due to either local heterogeneity in the distribution of bearing minerals or to redistribution with adsorption (e.g. Th on iron oxides). 


\subsection{Elemental mass transfer profiles within the in situ weathered horizons}

Table 6 reports the average open-system mass transport fractions $\tau_{\mathrm{j}, \mathrm{w}}$, their standard deviations and elemental gains and losses (in $10^{6} \mathrm{~mol} / \mathrm{ha}$ or $\mathrm{mol} / \mathrm{ha}$ ) for each horizon of the profile 1L6 calculated with average compositions.

Alkalis ( $\mathrm{Na}, \mathrm{K}, \mathrm{Rb})$, alkaline earths ( $\mathrm{Mg}, \mathrm{Ca}, \mathrm{Sr}, \mathrm{Ba})$, silica, $\mathrm{P}, \mathrm{Cd}, \mathrm{Cu}, \mathrm{Zn}, \mathrm{Ni}$ and $\mathrm{Co}$ show depletion profiles with depletion at the top, grading to parent concentration at depth. Alkalis $(\mathrm{Na}, \mathrm{K}, \mathrm{Rb})$ and alkaline earths $(\mathrm{Mg}$, $\mathrm{Ca}, \mathrm{Sr}, \mathrm{Ba})$ exhibit losses with $\tau_{\mathrm{j}, \mathrm{Zr}}$ ranging from -0.8 to -1.0 . This indicates the complete breakdown of oligoclase, $\mathrm{K}$-feldspar and hornblende crystals. Silica is moderately depleted in the saprolite $\left(\tau_{\mathrm{Si}, \mathrm{Zr}}-0.5\right)$ and more significantly depleted in the upper horizons with $\tau_{\mathrm{Si}, \mathrm{Zr}}$ down to -0.8 . Silica in the weathered materials is mainly controlled by quartz and kaolinite. The quartz content estimates and errors obtained from the linear inverse method (Tables 3 and 4) used to calculate the open-system mass transport fractions $\left(\tau_{\text {Quartz,Zr }}\right)$ in the different layers of the profile are showed in Fig. 6. Quartz loss in the saprolite reaches $30 \%$ and increases significantly in mottled clay, iron crust and topsoil with loss up to $70-80 \%$, with nonetheless large error bars. Some other elements as $\mathrm{P}, \mathrm{Cd}, \mathrm{Cu}, \mathrm{Zn}, \mathrm{Ni}$ and Co show depletion profiles with significant losses in the whole weathering profile $\left(\tau_{\mathrm{x}, \mathrm{Zr}}-0.8 /-0.6\right)$.

$\mathrm{Al}, \mathrm{Ga}, \mathrm{Ge}, \mathrm{Pb}, \mathrm{Fe}, \mathrm{V}, \mathrm{Cr}, \mathrm{U}, \mathrm{REE}$ and $\mathrm{Y}$ exhibit depletion-enrichment profiles with enrichment at various depths resulting from precipitation or translocation and a return to parent concentration at greater depth. The losses are moderate for $\mathrm{Al}, \mathrm{Ga}, \mathrm{Ge}$ and $\mathrm{Pb}$ in the whole weathering profile (minimum $\tau_{\mathrm{x}, \mathrm{Zr}}-0.60 /-0.05$ ). Redistribution of $\mathrm{Al}$, Ga and $\mathrm{Pb}$ at depth occurs in both ferruginous nodular horizon and saprolite. Ge is fractionated compared to $\mathrm{Si}$ with relative enrichment in Fe-rich horizon compared to saprolite and in mottled clay horizon and in topsoil $\left(\tau_{\mathrm{Ge}, \mathrm{Zr}}=-0.05\right)$ (Fig. 7). Among redox-sensitive elements, Fe, $\mathrm{V}$ and $\mathrm{Cr}$ show significant accumulation in the ferruginous nodular horizon with $\tau_{\mathrm{x}, \mathrm{Zr}}$ of $+1.5,+1.2,+0.4$, respectively. They are depleted in the saprolite, the mottled clay horizon and topsoil, moderately for $\mathrm{Fe}$ and $\mathrm{V}$ and more significantly for $\mathrm{Cr}$ (Fig. 8). Mn and Ce, two other important redox-sensitive elements, do not show significant redistribution linked to oxidative processes. $\mathrm{Mn}$ is lost all over the weathering profile $(-0.9)$ and slightly less in the topsoil $(-0.7)$. The Ce mass transfer does not differ from those of its neighbours La and Pr (Fig. 8). The LREE show an accumulation zone in the saprolite. Fig. 9 displays the REE fractionation according to the average open-system mass transport fraction for each horizon. The average loss of LREE is moderate in saprolite $(-0.1)$, with even a slight accumulation of $\mathrm{La}, \mathrm{Ce}$ and $\operatorname{Pr}\left(\right.$ e.g. $\left.\tau_{\mathrm{La}, \mathrm{Zr}}=+0.2\right)$. The LREE losses significantly increase in the above horizons to -0.8 . The losses of HREE $+Y$ are higher than those of LREE in saprolite (range from -0.6 to -0.2 ) and keep increasing in the mottled clay horizon and the iron crust $(-0.8)$, then decrease slightly in topsoil $(-0.7)$. $\mathrm{U}$ is depleted in the entire weathering profile with redistribution features in the iron crust.

\subsection{Elemental mass transfer profiles within the topsoil}

The loose clayey topsoil of lateritic weathering covers is known to be the place of intense biological activity and to be able to incorporate dusts from atmospheric inputs (Brimhall et al., 1988). It is considered as the current soil profile developing at the expense of the underlying iron crust (Tardy, 1993; Beauvais, 2009). Three possibilities have been proposed to explain the origin of the topsoil ((Tardy, 1993) and reference therein) particularly difficult to decipher due to the apparent homogeneity of the materials: (i) an autochthonous origin, exclusively derived from the degradation of the underlying iron crust material, (ii) an allochthonous origin by colluvionment and rework of material constituting the slope of the landscape and (iii) a mixed origin with material coming from deeper horizons from the same profile by input of fine mineral particles brought by the termite activity.

The studied topsoil, from 0 to $4.5 \mathrm{~m}$, homogeneous in texture (soft clayey) and structure (micro-aggregated), exhibits a steep threshold for most of the chemical elements at its transition with the underlying iron crust (i.e. soil production zone, see Fig. 3). The open-system mass transport fractions $\tau_{j, \mathrm{w}}$ were calculated with the average iron crust composition taken as parent material. The transfer profiles are shown in Fig. 10. It has to be noticed that, except K, the major alkaline and alkaline earth contents, are below the ICPAES detection limit within both the parent iron crust and in the topsoil. If we consider a margin of error of \pm 0.2 for both $\varepsilon_{\mathrm{Zr}, \mathrm{w}}$ and $\tau_{\mathrm{j}, \mathrm{Zr}}$, the depth profiles indicate that:

- The topsoil has likely undergone an isovolumetric weathering compared to the underlying iron crust (Fig. 10A).

- Apart from the organo-mineral first centimetres, $\mathrm{Si}, \mathrm{Rb}$, $\mathrm{Ni}, \mathrm{Co}$ and $\mathrm{Zn}$ are quite conservative in the topsoil.

- The topsoil is depleted in redox sensitive elements ( $\mathrm{Fe}$, $\mathrm{V}, \mathrm{Cr}$ ), Ba, K, Sr, Ge, Ga, Al, Co, Cu, U, REE (La) and $\mathrm{Th}$. The losses are quite constant for each element through the soil profile, with $\tau_{j, Z r}$ not exceeding -0.8 , and with, for most of them, an enrichment at $1 \mathrm{~m}$ depth followed by a depletion in the uppermost part of the topsoil.

These calculations indicate that the degradation of the iron crust is accompanied by the loss of most of the elements especially those accumulated in the iron crust as the redox sensitive elements $(\mathrm{Fe}, \mathrm{V}, \mathrm{Cr})$ and $\mathrm{Th}$.

\subsection{Contemporary elemental fluxes in the hillside lateritic system}

\subsubsection{Origin of the contemporary fluxes in the hillside spring} and seepage

On the watershed, the diluted meteoric water brings, in variable amounts, elements originating from sea salt aerosols (mainly $\mathrm{Na}$ and $\mathrm{Cl}$ ), terrigeneous particles, biogenic emissions from the vegetal cover and possible anthropogenic inputs. Passing through the hillside rainforest cover, 


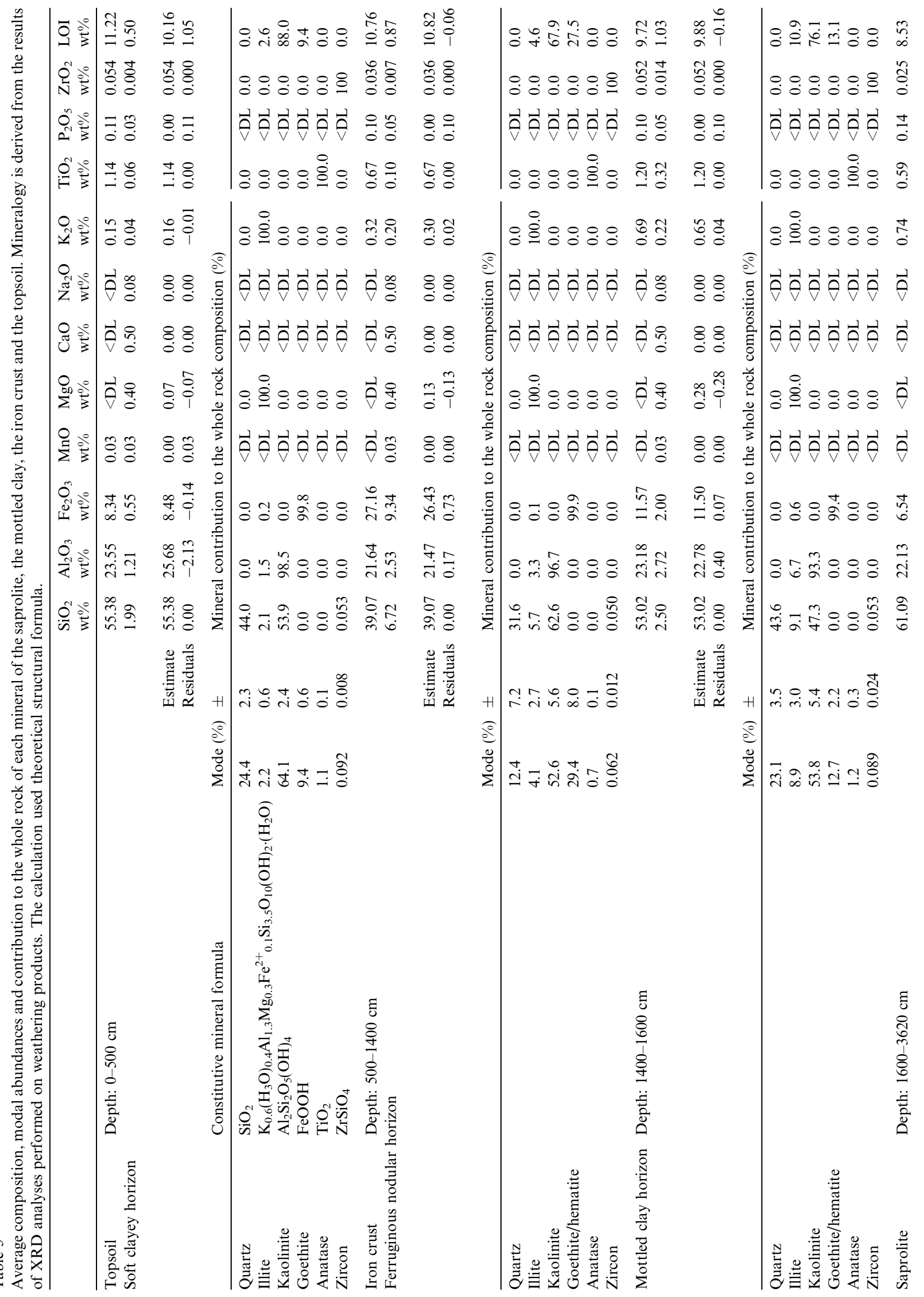




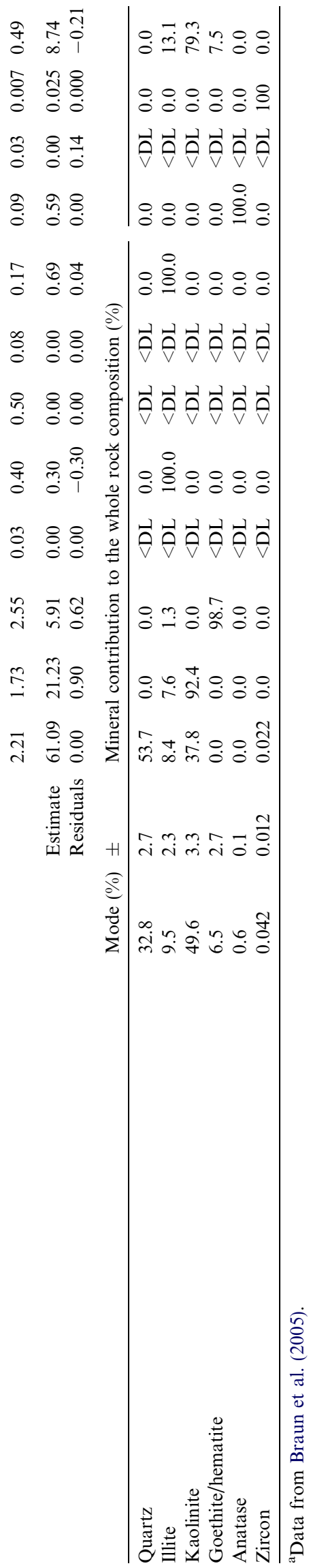

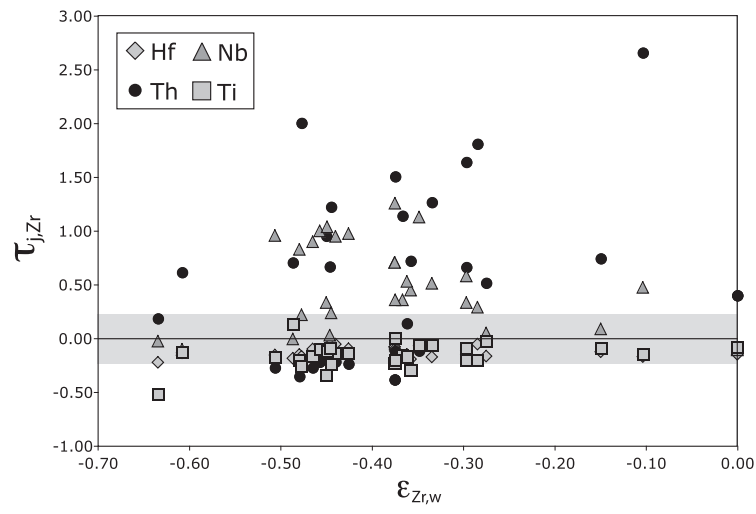

Fig. 5. Open-system mass transport fractions $\left(\tau_{j, \mathrm{w}}\right)$ for potential other immobile elements ( $\mathrm{Hf}, \mathrm{Nb}$, Th and $\mathrm{Ti}$ ) versus volumetric strain $\left(\varepsilon_{\mathrm{Zr}, \mathrm{w}}\right)$.

the meteoric water incorporates elements from leaf recretion (i.e. dominant in the throughfall signature) and vegetation decay (i.e. dominant in the litter leachate signature). Compared to rainfall, the water signature before infiltration into the ground is thus characterised by (i) high DOC contents (ii) significant enrichment in $\mathrm{Si}, \mathrm{K}, \mathrm{Ca}, \mathrm{Mg}$ and $\mathrm{Cl}$ and (iii) declining $\mathrm{Na} / \mathrm{Cl}$ ratios attesting to $\mathrm{Cl}$ inputs by vegetation if we consider $\mathrm{Na}$ as conservative and originating only from sea salts (see Table 3). When this water migrates through the vadose zone towards the topmost part of the 1L6 groundwater table, (i) the DOC content drastically falls under the detection limit $(<1 \mathrm{mg} / \mathrm{L})$, (ii) the $\mathrm{Si}, \mathrm{Mg}, \mathrm{Ca}, \mathrm{K}$ and $\mathrm{Cl}$ enrichment is no more observed and (iii) the $\mathrm{Na} / \mathrm{Cl}$ ratio is close to the marine ratio. Along with evaporation processes, that means that the infiltrating water likely undergoes several coupled processes affecting its chemistry as ion exchange, vegetation uptake and organic matter mineralisation by soil meso and microfauna. As per the rather inert nature of the lateritic vadose zone mainly composed of quartz, kaolinite and Fe-oxides and oxyhydroxides, we can considered that vegetation uptake and mineralisation dominate the base cation exchange processes. Except for Si for which the concentration reflects the equilibrium with phases like quartz and kaolinite, the topmost part of the groundwater has a signature of slightly concentrated rainwater by evaporation $(5 \times)$ and slightly enriched with elements coming from the cycling through vegetation $(\mathrm{Ca}, \mathrm{Mg}, \mathrm{K}$ ) with $\mathrm{Ca} / \mathrm{Cl}, \mathrm{Mg} / \mathrm{Cl}$ and $\mathrm{K} / \mathrm{Cl}$ are of $1.1,0.4$ and 0.7 , respectively. Towards the weathering front the influence of chemical weathering contribution becomes significant as indicated by the increase of the Cl-normalised ratios $(\mathrm{Ca} /$ $\mathrm{Cl}=4.7 ; \mathrm{Mg} / \mathrm{Cl}=1.5 ; \mathrm{K} / \mathrm{Cl}=1.9 ; \mathrm{Na} / \mathrm{Cl}=10.5)$ and the silica content $(280 \mu \mathrm{mol} / \mathrm{L})$.

The spring and seepage water may be considered as a mixing between (i) recharge water from the vadose zone, whose composition reflects the interaction with the vegetation cover and rain fall and (ii) water having interacted with primary weatherable minerals (mafic minerals, plagioclase, feldspars...) at deeper levels towards the weathering front (chemical weathering sensu stricto). At MEN1, the water is slightly acidic $(\mathrm{pH} \approx 4.5)$, free of suspended matter $(<0.1 \mathrm{mg} / \mathrm{L}$, detection limit $)$ and free of dissolved organic 


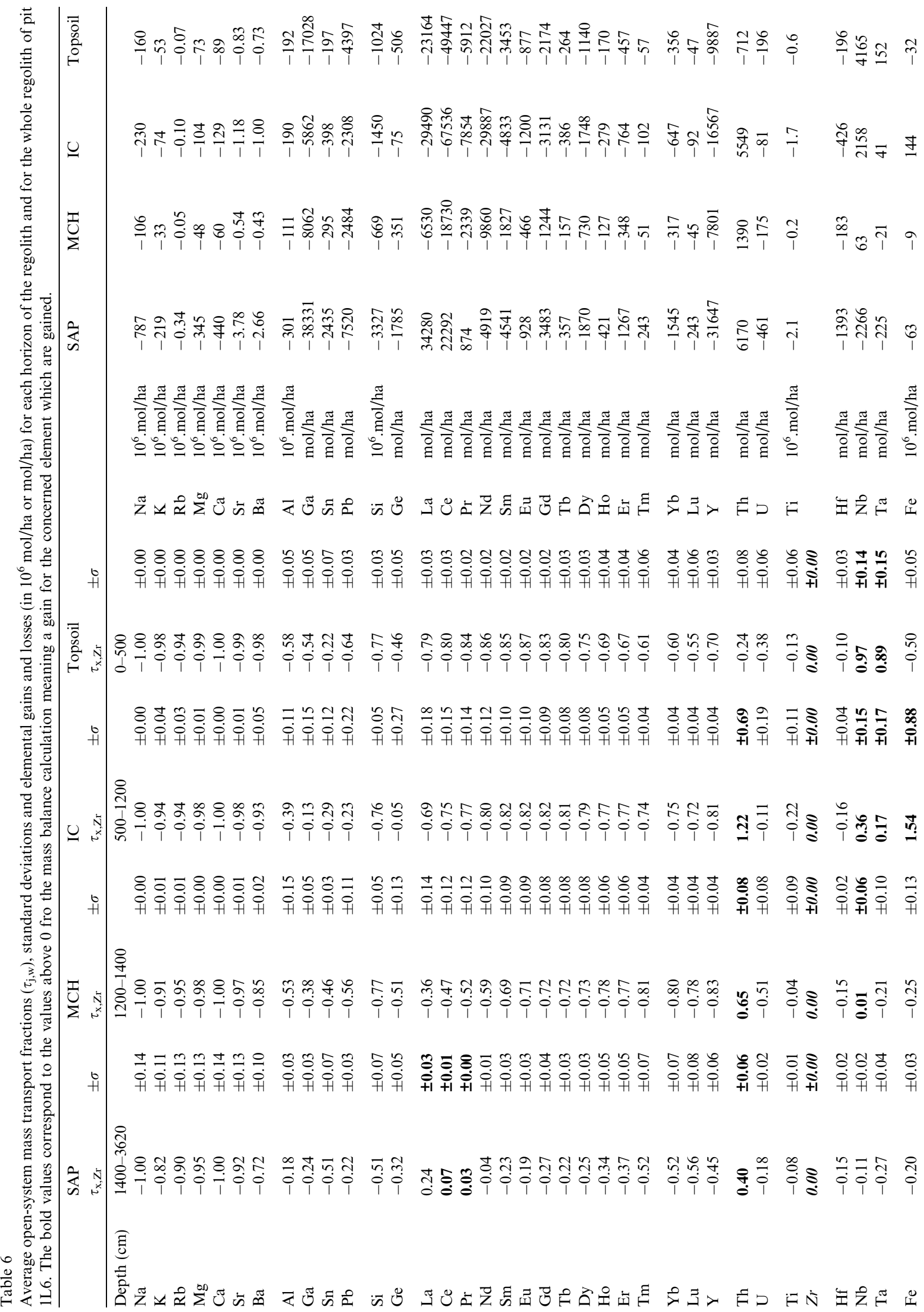




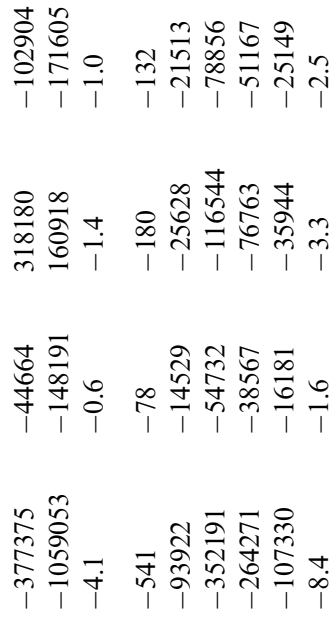

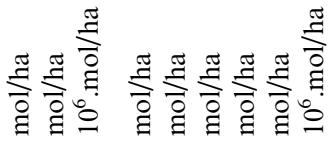

>

드응ㅎ의의

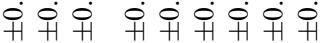

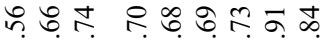

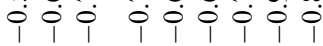

कㄷำ

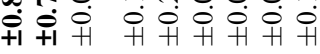

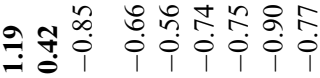

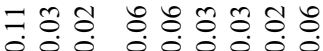

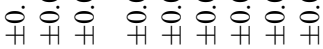

ก̋⿻

îl

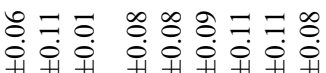

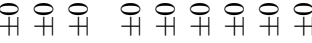

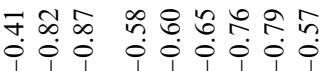

>

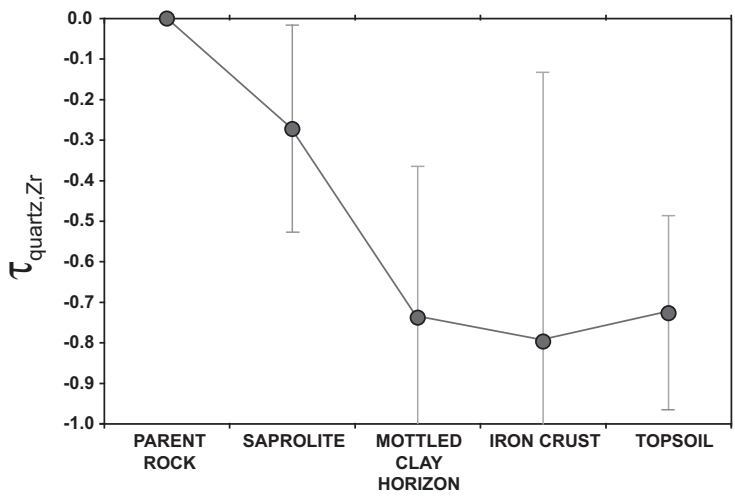

Fig. 6. Open-system mass transport fractions $\left(\tau_{\mathrm{j}, \mathrm{w}}\right)$ for quartz within the different horizons of the weathering profile $1 \mathrm{~L} 6$.

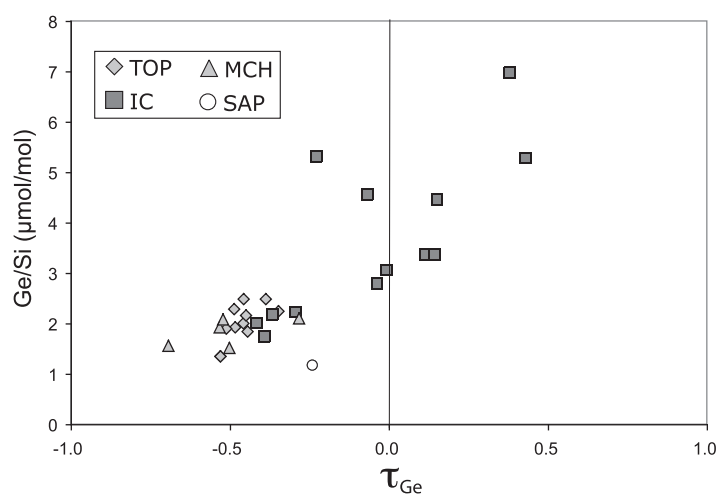

Fig. 7. Fractionation of Ge compared to $\mathrm{Si}$ within the different horizons of the pit 1L6 (TOP: soft clayey horizon; FNH, ferruginous nodular horizon; $\mathrm{MCH}$, mottled clay horizon; SAP, saprolite).

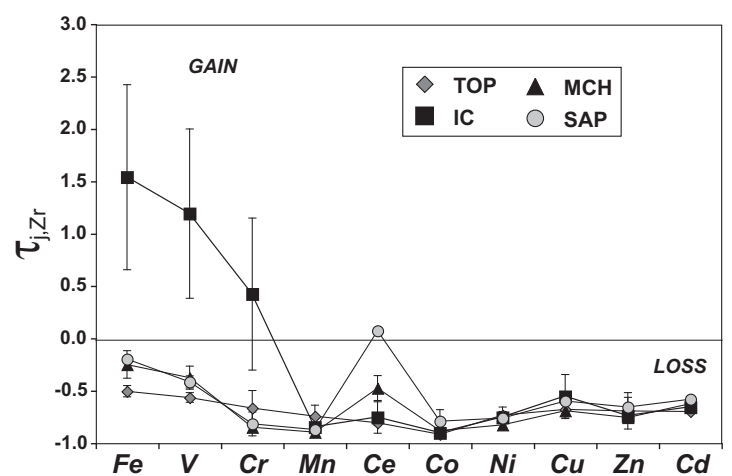

Fig. 8. Open-system mass transport fractions $\left(\tau_{j, \mathrm{w}}\right)$ for redox sensitive ( $\mathrm{Fe}, \mathrm{V}, \mathrm{Cr}, \mathrm{Mn}, \mathrm{Ce}$ ) and other metals (Co, Ni, Cu, $\mathrm{Zn}, \mathrm{Cd}$ ) within the different horizons of the pit 1L6.

carbon (DOC $<1 \mathrm{mg} / \mathrm{L}$, detection limit). The Cl-normalised ratio indicates that $\mathrm{Ca}$ and $\mathrm{K}$ are still controlled by vegetation decay/uptake $(\mathrm{Ca} / \mathrm{Cl}=1.0 ; \mathrm{K} / \mathrm{Cl}=0.4)$ and there is a significant contribution of chemical weathering for $\mathrm{Na}$ and $\mathrm{Mg}(\mathrm{Mg} / \mathrm{Cl}=1.2 ; \mathrm{Na} / \mathrm{Cl}=2.5)$. The outlet 


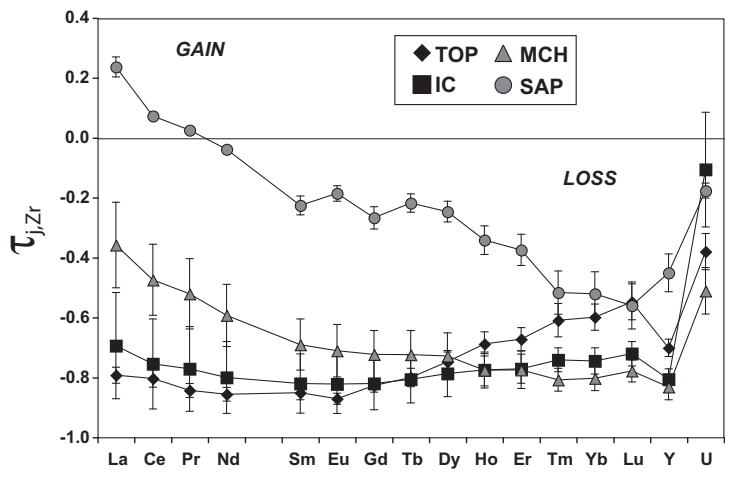

Fig. 9. Open-system mass transport fractions $\left(\tau_{j, \mathrm{w}}\right)$ for REE, Y and $\mathrm{U}$ within the different horizons of the pit 1L6.

water may be considered as the mixing between spring and seepage water, organic-rich overland flow water, rainwater and swamp groundwater. Unfortunately, the analyses of trace metals are not available for the topmost groundwater; hence further studies are needed to assess their origin in the fluxes (i.e. chemical weathering versus vegetation uptake/ decay).

\subsubsection{Determination of the recharge rate on the hillside system and quantification of the contemporary elemental fluxes}

The methodology used to determine the discharge of the groundwater in the swamp area from the hillside regolith is the Chloride Mass Balance (CMB) and is discussed in (Maréchal et al., 2011a). This method is based on the assumption that chlorine is conservative in the watershed, i.e. the $\mathrm{Cl}$ input from atmospheric wet deposits is equal to the $\mathrm{Cl}$ output in groundwater and stream, at a yearly to pluriannual basis. In the Nsimi watershed, the substratum is free of Cl-bearing minerals including evaporites and, during the time of the study, the watershed was carefully preserved

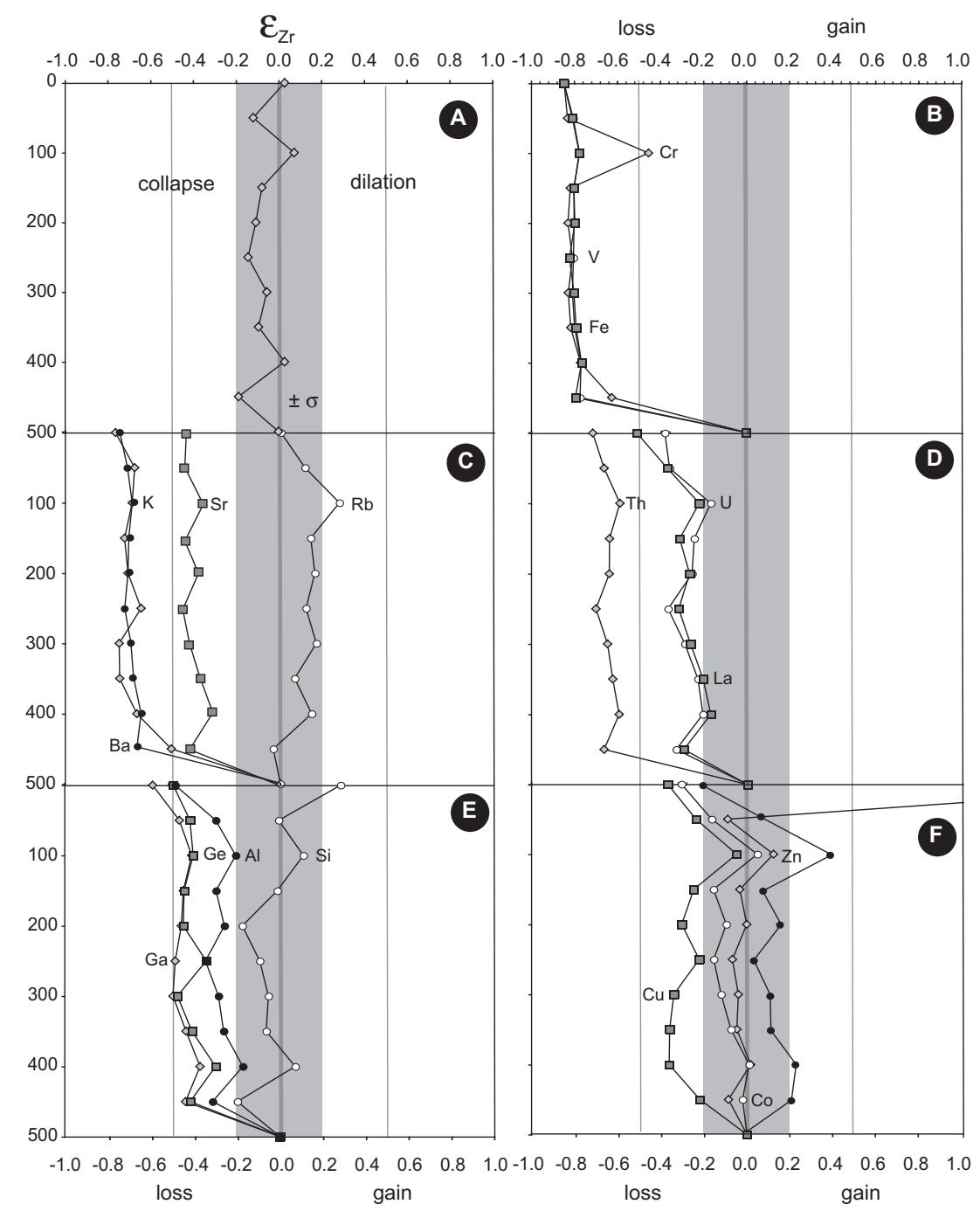

Fig. 10. Depth profiles for the volumetric strain $\left(\varepsilon_{\mathrm{Zr}, \mathrm{w}}\right)(\mathrm{A})$ and for trace elements $(\mathrm{B}-\mathrm{F})$ in the topsoil horizon with iron crust as a parent material reference. 
and prevented from burning and clearing. The $\mathrm{Na} / \mathrm{Cl}$ ratio in throughfalls varies from 0.07 to 0.65 (Table 3 ). This indicates that $\mathrm{Cl}$ is partly cycled through the vegetation at the rainy season scale, which is consistent with the nutrient status of $\mathrm{Cl}$ for plants (see review of (White and Broadley, 2001)). To avoid this effect of seasonal $\mathrm{Cl}$ cycling, the CMB was carried out on a pluriannual scale from 1994 to 1997, over three hydrological years.

Neglecting overland flow on the hillside, the CMB for hillside system is computed as:

$P[C l]_{p}=R_{\text {hill }}[\mathrm{Cl}]_{\text {hill }}$

with $P$ is the precipitation amount, $[\mathrm{Cl}]_{P}$ the volume weighted mean (VWM) chloride content in the precipitation, $R_{\text {hill }}$ the recharge rate on the hillside (related to the hillside surface area), $[\mathrm{Cl}]_{\text {hill }}$ the volume weighted mean (VWM) chloride content of hillside/weathering cover groundwater. A part of this water flows to the springs and seepages ( $\left.Q_{\text {hill }}\right)$ while the other part flows to the swamp ( $\left.Q_{\text {base }}\right)$. The water budget of hillside/weathering cover aquifer system, if a steady assumption is made (meaning that, at the water year level, there is no variation of the water table level), (Fig. 2) is:

$R_{\text {hill }}=Q_{\text {hill }}+Q_{\text {base }}$

with $Q_{\text {hill }}$ the total discharge rate of springs and seepage at the bottom of hillside $(\mathrm{mm} / \mathrm{yr})$ and $Q_{\text {base }}$ the groundwater deep flow from the hillside weathering cover aquifer to the swamp aquifer $(\mathrm{mm} / \mathrm{yr})$.

The CMB has been used for the 1994-1998 period for the spring (Maréchal et al., 2011a,b). According to the types of raingauges, the error is usually $5 \%$ on rainfall amount measurements. The runoff at the outlet has been measured using a Thalimedes OTT $^{\circledR}$ station which is generally known to generate an error of $10 \%$ on discharge rates. The analytical error associated with the Ionic Chromatograph equipment used for chloride content measurement is $\pm 5 \%$.

The spring MEN1 is the main outlet of the bedrock aquifer in the Nsimi watershed. In this highly recharged system, the water table constitutes a subdued replica of the topography. Its catchment can be adjusted to the head of the surface watershed, with a surface area of about $A_{\mathrm{MEN} 1}=90,000 \mathrm{~m}^{2}$ (Fig. $1 \mathrm{~B}$ ). Assuming that other springs and seepage points equally drain the rest of the bedrock/ regolith aquifer located below the hillside, we obtain:

$\frac{Q_{\mathrm{MENI}}}{Q_{\text {hill }}}=\frac{A_{\mathrm{MENI}}}{A_{\text {hill }}}$

with $A_{\text {hill }}\left(\mathrm{m}^{2}\right)$ the surface area of hillsides and $Q_{\mathrm{MEN} 1}$ the discharge rate at the spring MEN1 (mm/yr). This equation allows calculating the yearly contribution of bedrock aquifer to the streamflow, $Q_{\text {hill }}=305 \pm 53 \mathrm{~mm} / \mathrm{yr}$.

Assuming that the chloride content in the regolith/bedrock aquifer is equal to spring MEN1 chloride content, this leads to $R_{\text {hill }}=332 \mathrm{~mm} / \mathrm{yr}$. Then $Q_{\text {base }}$ is determined ( $Q_{\text {ba- }}$ $\mathrm{se}=27 \pm 34 \mathrm{~mm} / \mathrm{yr}$ ). All the flow rates are related to hillside surface area. Out of the $R_{\text {hill }}$ of $332 \mathrm{~mm} / \mathrm{yr}$ about $90 \%$ flows to the springs/brook and $10 \%$ flows to the swamp as base flow. This recharge rate represents $20 \%$ of the rainfall.

The elemental fluxes for the hillside zone $\left(F_{j, \text { hill }}\right)$ are assessed by:

$F_{j, \text { hill }}(\mathrm{mol} / \mathrm{ha} / \mathrm{yr})=C_{j, \mathrm{MEN} 1}(\mu \mathrm{mol} / \mathrm{L}) \cdot R_{\text {hill }}(\mathrm{mm} / \mathrm{yr}) / 100$

where $F_{j, \text { hill }}$ is the flux of element $j$ in the hillside system, $C_{j, \mathrm{MEN} 1}$ is the VWM of element $j$ in the spring MEN1 and $R_{\text {hill }}$ is the recharge rate in the hillside system (332 mm/yr, (Maréchal et al., 2011a))

The elemental fluxes at the outlet $\left(F_{j, \text { outlet }}\right)$ is assessed by:

$F_{j, \text { outlet }}(\mathrm{mol} / \mathrm{ha} / \mathrm{yr})=C_{j, \text { outlet }}(\mu \mathrm{mol} / \mathrm{L}) \cdot R_{\text {outlet }}(\mathrm{mm} / \mathrm{yr}) / 100$

where $F_{j \text {,outlet }}$ is the flux of element $j$ at the outlet, $C_{j \text {,outlet }}$ is the VWM of element $j$ at the outlet and $R_{\text {outlet }}$ is the surface runoff at the watershed scale $(378 \mathrm{~mm} / \mathrm{yr}$, (Braun et al., $2005))$. The elemental fluxes for the hillside zone $\left(F_{j, \text { hill }}\right)$ and at the outlet $\left(F_{j, \text { outlet }}\right)$ are reported in Table 7.

The elemental contributions of the swamp to the outlet flux $(\mathrm{in} \%)$ is calculated by:

$$
\begin{aligned}
\% F_{\text {swamp }}= & 100\left[F_{j, \text { outlet }}(\mathrm{mol} / \mathrm{ha} / \mathrm{yr}) S_{\text {outlet }}(\text { ha })\right. \\
& \left.-F_{j, \text { hill }}(\mathrm{mol} / \mathrm{ha} / \mathrm{yr}) S_{\text {hill }}(\text { ha })\right] / \\
& {\left[F_{j, \text { outlet }}(\mathrm{mol} / \mathrm{ha} / \mathrm{yr}) S_{\text {outlet }}(\text { ha })\right] }
\end{aligned}
$$

with $S_{\text {outlet }}=60$ ha and $S_{\text {hill }}=48$ ha, the respective surface areas for the whole watershed and the hillside system. The results are reported in Table 7.

Overall, the elemental fluxes are extremely low at the hillside lateritic system level. Out of the $77 \mathrm{~mol} / \mathrm{ha} / \mathrm{yr}$ of $\mathrm{Na}$ flux, corrected from atmospheric deposits, $72 \mathrm{~mol} / \mathrm{ha} /$ yr may be attributed to the current weathering rates of plagioclase crystals (oligoclase/albite, $94 \%$ of the composite parent rock) and the remaining $5 \mathrm{~mol} / \mathrm{ha} / \mathrm{yr}$ to the breakdown of hornblende ( $6 \%$ of the composite parent rock). The silica hillside flux is $300 \mathrm{~mol} / \mathrm{ha} / \mathrm{yr}$ and can be attributed to plagioclase dissolution, and maybe to a lesser extent to kaolinite dissolution. $\mathrm{Al}$ and $\mathrm{Ga}$ are exported from the lateritic weathering cover due to the dissolution of plagioclase and kaolinite crystals. Compared to other immobile elements ( $\mathrm{Zr}, \mathrm{Hf}, \mathrm{Nb}$ and $\mathrm{Th}$ ), $\mathrm{Ti}$ is significantly exported. Among redox-sensitive elements ( $\mathrm{Fe}, \mathrm{V}, \mathrm{Cr}, \mathrm{Mn}, \mathrm{Ce}$ ), only $\mathrm{Ce}$ and $\mathrm{Mn}$ are exported out of the hillside system meaning that the water is mildly oxidising, less than in other studied profiles where $\mathrm{CeO}_{2}$ precipitates (Braun et al., 1998). The other elements $(\mathrm{Fe}, \mathrm{V}, \mathrm{Cr})$ are likely able to be mobilised but over a short distance only, they are not exported out of the hillside system. $\mathrm{Rb}, \mathrm{Sr}, \mathrm{Ba}, \mathrm{Ni}, \mathrm{Cu}, \mathrm{Zn}$ are affected by export processes. LREE and $\mathrm{Y}$ are exported but in very low amounts (in the $\mu \mathrm{mol} / \mathrm{ha} / \mathrm{yr}$ to $\mathrm{mmol} / \mathrm{ha} / \mathrm{yr}$ range) while HREE and $U$ are quite immobile.

The elemental export by the stream can be sorted out by being: (i) Primarily controlled by the swamp $\left(80 \leqslant \% F_{\text {swamp }} \leqslant 100 \%\right)$ as Th, Zr, U, LREE, HREE + Y, $\mathrm{Cu}, \mathrm{Fe}, \mathrm{Cr}, \mathrm{V}, \mathrm{Zr}, \mathrm{Hf}, \mathrm{Nb}$, Ti and $\mathrm{Al}$, (ii) significantly controlled $\left(60 \leqslant \% F_{\text {swamp }} \leqslant 80 \%\right)$ as $\mathrm{Na}, \mathrm{Rb}, \mathrm{Sr}, \mathrm{Mn}, \mathrm{Ni}, \mathrm{K}$, $\mathrm{Ca}, \mathrm{Ba}, \mathrm{Zn}$ and $\mathrm{Ga}$ and (ii) moderately controlled $\left(\% F_{\text {swamp }} \leqslant 60 \%\right)$ as $\mathrm{Mg}$, Co and $\mathrm{Si}$. 
Table 7

Contemporary elemental fluxes for the hillside zone $\left(F_{j, \text { hill }}\right)$ and at the outlet $\left(F_{j, \text { outlet }}\right)$ and the elemental contributions of the swamp to the outlet flux $\left(\% F_{j, \text { swamp }}\right)$ are also reported. The calculation are carried out with (\#) $R_{\text {hill }}=332 \pm 61 \mathrm{~mm} / \mathrm{yr}$, (\#\#) $R_{\text {outlet }}=378 \pm 38 \mathrm{~mm} / \mathrm{yr}$, ( $)$ $\mathrm{Na}^{*}$ with $\mathrm{Cl}_{\mathrm{VwM}}=11.5 \mu \mathrm{mol} / \mathrm{L} ;(\S \S) \mathrm{Na}^{*}$ with $\mathrm{Cl}_{\mathrm{VwM}}=10.8 \mu \mathrm{mol} / \mathrm{L}$.

\begin{tabular}{|c|c|c|c|c|c|c|}
\hline & & $\begin{array}{l}{ }^{\#} F_{\text {hill }} \\
\S\end{array}$ & $\pm 1 \sigma$ & $\begin{array}{l}{ }^{\# \#} F_{\text {outlet }} \\
\S \S\end{array}$ & $\pm 1 \sigma$ & $\% F_{\text {swamp }}$ \\
\hline $\mathrm{Mg}$ & $\mathrm{mol} / \mathrm{ha} / \mathrm{yr}$ & 34 & \pm 7 & 61 & \pm 6 & 44 \\
\hline $\mathrm{K}$ & $\mathrm{mol} / \mathrm{ha} / \mathrm{yr}$ & 16 & \pm 3 & 36 & \pm 4 & 56 \\
\hline $\mathrm{Ca}$ & $\mathrm{mol} / \mathrm{ha} / \mathrm{yr}$ & 65 & \pm 13 & 130 & \pm 13 & 50 \\
\hline $\mathrm{Na}^{*}$ & $\mathrm{~mol} / \mathrm{ha} / \mathrm{yr}$ & 77 & \pm 15 & 195 & \pm 20 & 61 \\
\hline $\mathrm{Rb}$ & $\mathrm{mol} / \mathrm{ha} / \mathrm{yr}$ & 0.011 & \pm 0.00 & 0.032 & \pm 0.00 & 64 \\
\hline $\mathrm{Sr}$ & $\mathrm{mol} / \mathrm{ha} / \mathrm{yr}$ & 0.213 & \pm 0.04 & 0.776 & \pm 0.08 & 73 \\
\hline $\mathrm{Ba}$ & $\mathrm{mol} / \mathrm{ha} / \mathrm{yr}$ & 0.279 & \pm 0.06 & 0.672 & \pm 0.07 & 58 \\
\hline $\mathrm{Al}$ & $\mathrm{mol} / \mathrm{ha} / \mathrm{yr}$ & 1.890 & \pm 0.38 & 44.324 & \pm 4.46 & 96 \\
\hline $\mathrm{Ga}$ & $\mathrm{mol} / \mathrm{ha} / \mathrm{yr}$ & 0.015 & \pm 0.00 & 0.037 & \pm 0.00 & 59 \\
\hline $\mathrm{Si}$ & $\mathrm{mol} / \mathrm{ha} / \mathrm{yr}$ & 303 & \pm 60.60 & 486 & \pm 49 & 38 \\
\hline $\mathrm{Ti}$ & $\mathrm{mol} / \mathrm{ha} / \mathrm{yr}$ & 0.020 & \pm 0.004 & 0.148 & \pm 0.015 & 87 \\
\hline $\mathrm{Zr}$ & $\mathrm{mol} / \mathrm{ha} / \mathrm{yr}$ & $<\mathrm{DL}$ & & 0.01441 & 0.00145 & 100 \\
\hline $\mathrm{Hf}$ & $\mathrm{mol} / \mathrm{ha} / \mathrm{yr}$ & $<\mathrm{DL}$ & & 0.00023 & 0.00002 & 100 \\
\hline $\mathrm{Nb}$ & $\mathrm{mol} / \mathrm{ha} / \mathrm{yr}$ & $<\mathrm{DL}$ & & 0.00035 & 0.00003 & 100 \\
\hline V & $\mathrm{mol} / \mathrm{ha} / \mathrm{yr}$ & $<\mathrm{DL}$ & & 0.096 & \pm 0.010 & 100 \\
\hline $\mathrm{Cr}$ & $\mathrm{mol} / \mathrm{ha} / \mathrm{yr}$ & $<\mathrm{DL}$ & & 0.127 & \pm 0.013 & 100 \\
\hline $\mathrm{Mn}$ & $\mathrm{mol} / \mathrm{ha} / \mathrm{yr}$ & 0.283 & \pm 0.057 & 0.820 & \pm 0.082 & 66 \\
\hline $\mathrm{Fe}$ & $\mathrm{mol} / \mathrm{ha} / \mathrm{yr}$ & $<\mathrm{DL}$ & & 25 & 3 & 100 \\
\hline Co & $\mathrm{mol} / \mathrm{ha} / \mathrm{yr}$ & 0.011 & \pm 0.002 & 0.018 & \pm 0.002 & 40 \\
\hline $\mathrm{Ni}$ & $\mathrm{mol} / \mathrm{ha} / \mathrm{yr}$ & 0.038 & \pm 0.008 & 0.107 & \pm 0.011 & 65 \\
\hline $\mathrm{Cu}$ & $\mathrm{mol} / \mathrm{ha} / \mathrm{yr}$ & 0.012 & \pm 0.002 & 0.057 & \pm 0.006 & 79 \\
\hline $\mathrm{Zn}$ & $\mathrm{mol} / \mathrm{ha} / \mathrm{yr}$ & 0.089 & \pm 0.018 & 0.217 & \pm 0.022 & 59 \\
\hline $\mathrm{La}$ & $\mathrm{mol} / \mathrm{ha} / \mathrm{yr}$ & 0.001781 & \pm 0.000356 & 0.007628 & \pm 0.000767 & 77 \\
\hline $\mathrm{Ce}$ & $\mathrm{mol} / \mathrm{ha} / \mathrm{yr}$ & 0.002401 & \pm 0.000480 & 0.017364 & \pm 0.001746 & 86 \\
\hline $\operatorname{Pr}$ & $\mathrm{mol} / \mathrm{ha} / \mathrm{yr}$ & 0.000305 & \pm 0.000061 & 0.002007 & \pm 0.000202 & 85 \\
\hline $\mathrm{Nd}$ & $\mathrm{mol} / \mathrm{ha} / \mathrm{yr}$ & 0.001139 & \pm 0.000228 & 0.007955 & \pm 0.000800 & 86 \\
\hline $\mathrm{Sm}$ & $\mathrm{mol} / \mathrm{ha} / \mathrm{yr}$ & 0.000285 & \pm 0.000057 & 0.001594 & \pm 0.000160 & 82 \\
\hline $\mathrm{Eu}$ & $\mathrm{mol} / \mathrm{ha} / \mathrm{yr}$ & 0.000023 & \pm 0.000005 & 0.000347 & \pm 0.000035 & 93 \\
\hline Gd & $\mathrm{mol} / \mathrm{ha} / \mathrm{yr}$ & 0.000109 & \pm 0.000022 & 0.001148 & \pm 0.000115 & 90 \\
\hline $\mathrm{Tb}$ & $\mathrm{mol} / \mathrm{ha} / \mathrm{yr}$ & 0.000004 & \pm 0.000001 & 0.000150 & \pm 0.000015 & 97 \\
\hline Dy & $\mathrm{mol} / \mathrm{ha} / \mathrm{yr}$ & 0.000026 & \pm 0.000005 & 0.001007 & \pm 0.000101 & 97 \\
\hline Ho & $\mathrm{mol} / \mathrm{ha} / \mathrm{yr}$ & $<\mathrm{DL}$ & & 0.000181 & \pm 0.000018 & 100 \\
\hline $\mathrm{Er}$ & $\mathrm{mol} / \mathrm{ha} / \mathrm{yr}$ & $<\mathrm{DL}$ & & 0.000509 & \pm 0.000051 & 100 \\
\hline $\mathrm{Tm}$ & $\mathrm{mol} / \mathrm{ha} / \mathrm{yr}$ & $<\mathrm{DL}$ & & 0.000045 & \pm 0.000005 & 100 \\
\hline $\mathrm{Yb}$ & $\mathrm{mol} / \mathrm{ha} / \mathrm{yr}$ & 0.000014 & \pm 0.000003 & 0.000478 & \pm 0.000048 & 97 \\
\hline $\mathrm{Lu}$ & $\mathrm{mol} / \mathrm{ha} / \mathrm{yr}$ & $<\mathrm{DL}$ & & 0.000057 & \pm 0.000006 & 100 \\
\hline Y & $\mathrm{mol} / \mathrm{ha} / \mathrm{yr}$ & 0.001525 & \pm 0.000305 & 0.009884 & \pm 0.000994 & 85 \\
\hline Th & $\mathrm{mol} / \mathrm{ha} / \mathrm{yr}$ & $<\mathrm{DL}$ & & 0.001651 & \pm 0.000166 & 100 \\
\hline $\mathrm{U}$ & $\mathrm{mol} / \mathrm{ha} / \mathrm{yr}$ & $<\mathrm{DL}$ & & 0.000260 & \pm 0.000026 & 100 \\
\hline
\end{tabular}

5.5.3. Assessment of the contemporary saprolite production rate and aggressiveness of the draining waters with respect to the primary mineral weathering assemblage

The amount and timing of the water flux determines the rate of chemical weathering reactions (i.e. acid-base, ion exchange, redox and mineral transformation reactions) and hence the trajectory of the evolution of the weathering cover (Berner, 1978; Chadwick and Chorover, 2001; Lin, 2010). The aggressiveness of the draining waters with respect to primary and/or secondary minerals will depend on their saturation index, which indicates the saturation of the solution with respect to a given secondary mineral either in the waterlogged part of the regolith or in the vadose zone. The saturation index will tend to increase with increasing rate of precursor mineral dissolution but will decrease as increasing water flux (i.e. recharge) leaches solutes. Precipitation and evapo-transpiration are hence critical determinants of recharge/discharge of groundwater and weathering reactions (Chadwick and Chorover, 2001).

In order to get a deeper insight into the dynamics of the lateritic terrains in humid Tropics and how the chemical weathering proceeds in such an environment with respect to (i) the combined effect of precipitation and evapotranspiration on the aggressiveness of the draining solutions at the 
weathering front and (ii) the contemporary saprolite production rates, we propose to compare the 1L6 profile from Nsimi SEW to the BH5 monitored ridge top weathering profile from Mule Hole SEW, South India. Both profiles have developed on granito-gneissic Precambrian basements, mainly granodioritic in composition, with dominant plagioclase/albite phases. Thanks to the thorough geochemical, mineralogical and hydrological studies and using the CMB approach (see previous section), we were able to assess the water recharge $\left(R_{\text {hill }}\right)$ and the chemical weathering fluxes in both ridge top profiles (Soumya et al., 2009; Maréchal et al., 2011a,b).

The Mule Hole SEW presents the contemporary weathering conditions for an immature weathering cover under sub-humid climate with one rainy season of limited extension (three months) per hydrological year (Braun et al., 2009; Marechal et al., 2009; Soumya et al., 2009; Ruiz et al., 2010). Over a period of 40 years, the MAR is $1280 \pm 380 \mathrm{~mm} / \mathrm{yr}$ with a coefficient of variation of $30 \%$ (Javeed et al., 2009; Javeed, 2010). The dry deciduous forest vegetation induces an elevated AET of $1100 \mathrm{~mm} / \mathrm{yr}(85 \%$ of MAR) (Marechal et al., 2009; Ruiz et al., 2010). The recharge $\left(R_{\text {hill }}\right)$ is $45 \mathrm{~mm} / \mathrm{yr}$ out of which $100 \%$ of the solutes are discharged through the groundwater as underflow from the watershed. The superficial soil horizons still contain plagioclase crystals indicating the immaturity of the weathering cover. The vadose zone thickness extent to up to $36 \mathrm{~m}$ within the top ridge profile (BH5) (Braun et al., 2009) and the groundwater flows mainly in the fractured rock aquifer, leaving the saprolite aquifer unsaturated most of the time. The groundwater has a quite stable composition throughout the year with $\mathrm{TZ}+$ of $7000 \mu \mathrm{eq} / \mathrm{L}$ and silica content of $780 \mu \mathrm{mol} / \mathrm{L}$ (Violette et al., 2010). The erosion processes are highly active on the hillside (Barbiéro et al., 2007).

At Nsimi, the coefficient of variation of annual rain is low $(16 \%)$ and hence the coefficient of variation of recharge is also low. Moreover the recharge is relatively uniform intra-year due to the distribution within a year with two rainy seasons. This results in a uniform discharge of the pore water each year and hence leads to a uniform development of a mature saprolite horizon with a sharp weathering front. At Mule Hole, the coefficient of variation of annual rainfall is significantly higher $(30 \%$, (Javeed et al., 2009; Javeed, 2010)) and hence the coefficient of variation of annual recharge is also higher than at Nsimi. Further the rainfall within a year is predominantly concentrated in three months, which results in a time limited water-rock interaction and leading to non-uniformly developed weathering front (gradually decreasing maturation of the profile) in the saprolite. Since the weathering front is not a sharp threshold unlike at Nsimi, the pore water can be concentrated to a higher level during its pathway to the fractured rock. As the pore water appearing above the fractured zone is already highly concentrated due to the continuous breakdown of primary minerals, in the case of Mule Hole, there is less opportunity for chemical weathering in the fractured zone. Hence in comparison with Nsimi, there is a significant retardation of the development of saprolite horizon.
We can consider, on a decadal time frame both at the pristine forested watersheds of Nsimi and Mule Hole, that the mean annual groundwater discharge is equal to the mean annual recharge $\left(R_{\text {hill }}=Q_{\text {hill }}\right)$. So, the estimated groundwater discharge at Mule Hole ( $45 \mathrm{~mm} / \mathrm{yr})$ is approximatively six times lower than at Nsimi $(332 \mathrm{~mm} / \mathrm{yr})$. Even though the groundwater discharge at Mule Hole is smaller than at Nsimi, the pore water concentration from the fractured zone at Mule Hole is 12 times higher than at Nsimi weathering front, which results in a higher mass of elements being leached at Mule Hole. Considering (i) Na as representative of the dissolution of plagioclase crystals and conservative during saprolitization processes and (ii) steady state of the inter-annual recharge for a 10 years period, the current saprolite production rates $\left(\sigma_{T}\right.$, in $\left.\mathrm{mm} / \mathrm{kyr}\right)$ can be assessed by:

$\sigma_{T}=\frac{F_{\mathrm{Na}, \text { hillside }}}{\left(X_{\mathrm{Na}, \text { parentrock }}-X_{\mathrm{Na} \text {,saprolite }}\right)}$

where $F_{\mathrm{Na} \text {,hillside }}$ is the flux of sodium leached from the weathering profile (in $\left.\mathrm{g} / \mathrm{m}^{2} / \mathrm{yr}\right)\left(F_{\mathrm{Na} \text {,hillside }}=R_{\text {hill }}[\mathrm{Na}]_{\text {ground- }}\right.$ water $\backslash$ output with $R_{\text {hill }}$ is the recharge and [ $\left.\mathrm{Na}\right]_{\text {groundwater } \backslash \text { output }}$ the concentration of $\mathrm{Na}$ in the groundwater discharge from the system corrected from atmospheric deposit inputs). $X_{\mathrm{Na} \text {,saprolite }}$ and $X_{\mathrm{Na} \text {,saprolite }}$ are the fraction of sodium (i) in the parent rock and (ii) content remaining in the saprolite (in $\mathrm{g} / \mathrm{m}^{3}$ ), respectively. $X_{\mathrm{Na} \text {,saprolite }}$ tends towards zero when plagioclase crystals are completely broken down and $\mathrm{Na}$ leached away from the saprolite (e.g. case of Nsimi). The resulting saprolite production rates are $22 \mathrm{~mm} / \mathrm{kyr}$ at Mule Hole and $2 \mathrm{~mm} / \mathrm{kyr}$ at Nsimi meaning that even with high discharge, the importance of the maturity of the weathering cover coupled with the hydrological functionning remains a fundamental forcing for the solute export, chemical weathering and the shape of the weathering front.

\subsection{Implication on the long-term evolution of lateritic terrains in the humid Tropics}

The multiconvex landform of the Interior Surface of the South Cameroun Plateau, whose elevation is between 600 and $800 \mathrm{~m}$, is supposed to originate from the dismantling of an old iron crust formerly developed in contrasted drier climatic conditions. Field works and remote sensing approaches in the upper Nyong basin, (Bitom et al., 2004) suggest that the conjunction of climatic variations and forest dynamics as well as the hydrostatic level fluctuation and the lateritic heritages in the weathering cover have controlled the landform evolution in the current rainforest zone of Africa. The dense secondary hydrographic network may have incised previous landforms while the hydrostatic level remained stable or even migrated upwards. This has led to vertical downward decay of the lateritic weathering cover. However, the South Cameroon Plateau was not always covered with rainforest and had heavy rainfall. Paleohydrological and paleoclimatological investigations covering the last $10,000 \mathrm{yr}$ interglacial period (Holocene) have pointed out that the region has undergone alternating wet and drought periods leading, for the rainforest, to either its expansion during wet intervals or its contraction during drought 
periods with set up of savanna (Ngomanda et al., 2007, 2009). The long term precipitation changes in monsoon regime during the past 20,000 yrs in Central Africa are mostly related to changes in ocean circulation and sea surface temperature patterns, which are important to modulate atmospheric moisture transport (Schefusz et al., 2005; Weldeab et al., 2005). The influence on this alternating regime on a long term period (i.e. $\geqslant 1 \mathrm{Myr}$ ) would have influenced the balance between both weathering and erosion processes, hence denudation processes, but not enough to strip off the landforms as it has occurred in the sub-humid and arid part in South India (i.e. the Kabini River basin, case of Mule Hole SEW) (Gunnell, 1998; Gunnell et al., 2003; Braun et al., 2009).

The only existing information about the age of the Interior Surface, South Cameroon Plateau, are found in the synthesis of (Tardy and Roquin, 1998). The authors, based on previous attempts of relative dating of the erosion surfaces of Central Africa (Segalen, 1967; Fritsch, 1978; Morin, 1989) proposed a plausible Miocene age (7-20 Myr).

In order to assess the saprolite residence time and the average saprolite production rate (i.e. the migration rate of the weathering front into the fresh bedrock, see also (Velbel, 1985; Pavich, 1989; Price et al., 2008)) over long period of time (i.e. $\geqslant \mathrm{Myr}$ ), we have adapted the method from (Dosseto et al., 2008) coupled with the relative estimates of age of the Interior Surface of the South Cameroon Plateau given in (Tardy and Roquin, 1998) to be applied to the $\mathrm{Na}$ leaching rate.

The saprolite residence time $\tau_{\text {saprolite }}$ is given by:

$\tau_{\text {saprolite }}=\frac{h_{\text {saprolite }}}{\varepsilon_{\text {saprolite }}}$

with $\tau_{\text {saprolite }}$ (in Myr) is the saprolite residence time, $h_{\text {sapro- }}$ lite is the height of the saprolite (in m) and $\varepsilon_{\text {saprolite }}$ is the saprolite production rate (in $\mathrm{m} / \mathrm{Myr}$ ). $\tau_{\text {saprolite }}$ is then used in the expression allowing to calculate the average flux of $\mathrm{Na}$ leached out of the profile over long period:

$\bar{F}_{\mathrm{Na} \text {,saprolite }}=\frac{\Delta M_{\mathrm{Na} \text {,saprolite }}}{\tau_{\text {saprolite }}}=\frac{\Delta M_{\mathrm{Na} \text {, saprolite }} \cdot \varepsilon_{\text {saprolite }}}{h_{\text {saprolite }}}$

where $\bar{F}_{\text {Na,saprolite }}$ corresponds to the average flux of Na produced during the formation of the saprolite and $\Delta M_{\mathrm{Na} \text {,sap- }}$ rolite the total mass of $\mathrm{Na}$ transferred from the saprolite. If we assume that the saprolite production rate might oscillate between 2 and $25 \mathrm{~m} / \mathrm{Myr}$, range generally admitted for shield landscapes in humid Tropics (i.e. transport-limited environment, (Thomas, 2006)), for a saprolite thickness of $22.2 \mathrm{~m}$ (1L6, Nsimi), the average $\mathrm{Na}$ flux $F_{\mathrm{Na} \text {,saprolite }}$ $F \_$Na,saprolite $\}$would vary from 70 to $890 \mathrm{~mol} / \mathrm{ha} / \mathrm{yr}$ for residence times $\tau_{\text {saprolite }}$ oscillating from 11 to 0.8 $\mathrm{Myr}$, respectively. If we consider (i) the contemporary $\mathrm{Na}$ flux being in the lower range $F_{\mathrm{Na} \text {,hillside }}=77 \pm 15 \mathrm{~mol} / \mathrm{ha} /$ $\mathrm{yr} ; \sigma_{\mathrm{T}}=2 \mathrm{~mm} / \mathrm{kyr}$ ), (ii) the Miocene age (average $15 \mathrm{Myr}$ ) of the South Cameron Plateau landscape and (iii) the limited movement of Africa continent (Parrish et al., 1982) leading to its Central part has remained at equatorial latitudes since Eocene ( $46 \pm 8 \mathrm{Myr}$ ), the saprolite production rate should have remain in the lower range, from 2 to $10 \mathrm{~m} / \mathrm{Myr}$. We therefore agree with the statement of
(Dosseto et al., 2008) based on U-Th method, who suggested that, for thick weathering profiles, although the extent of weathering strongly differs between temperate and tropical climates, the migration of the weathering front into the bedrock occurs at a relatively uniform rate regardless of present-day climatic conditions. Climate variation leading to the alternation of setup of savanna or humid forest will have an effect on physical erosion rather than chemical erosion for such deep weathering profiles.

\section{CONCLUSION}

The assessment of past and present chemical weathering fluxes for major and trace elements of the Nsimi hillside weathering cover indicates that:

- The mass balance calculation integrating the gain or loss of elements over the weathering profile history exhibits (i) strong depletion profiles for alkalis $(\mathrm{Na}, \mathrm{K}, \mathrm{Rb})$ and alkaline earths $(\mathrm{Mg}, \mathrm{Ca}, \mathrm{Sr}, \mathrm{Ba})$, (ii) moderate depletion profiles for $\mathrm{Si}, \mathrm{P}, \mathrm{Cd}, \mathrm{Cu}, \mathrm{Zn}, \mathrm{Ni}$ and $\mathrm{Co}$, (iii) depletion/enrichment profiles for $\mathrm{Al}, \mathrm{Ga}, \mathrm{Ge}, \mathrm{Sn}$, $\mathrm{Pb}, \mathrm{LREE}, \mathrm{HREE}, \mathrm{Y}, \mathrm{U}, \mathrm{Fe}, \mathrm{V}, \mathrm{Cr}, \mathrm{Mn}$. It is noteworthy that (i) $\mathrm{Mn}$ and $\mathrm{Ce}$ are not significantly redistributed according to oxidative processes as it is the case for $\mathrm{Fe}$, $\mathrm{V}$ and $\mathrm{Cr}$, and (ii) $\mathrm{Ge}$ is fractionated compared to silica with enrichment in Fe-rich horizons. In the topsoil, the mass balance calculations performed with the iron crust composition as parent material reference indicate that the degradation is accompanied by the loss of most of the elements especially those accumulated in the iron crust as the redox sensitive elements $(\mathrm{Fe}, \mathrm{V}, \mathrm{Cr})$ and $\mathrm{Th}$.

- The loss of $\mathrm{Na}$ is mostly attributed to plagioclase breakdown $(94 \%)$ and to a lesser extend to hornblende $(6 \%)$. The loss of $\mathrm{Si}$ is mainly due to plagioclase/feldspar crystal dissolution $(47.4 \%)$ and ferromagnesian minerals $(17.2 \%)$. The $\mathrm{K}$ loss is attributed to the dissolution of $\mathrm{K}$-feldspar $(60 \%)$ and hornblende $(40 \%)$. The $\mathrm{Ca}$ is provided by the dissolution of epidote and hornblende $(>60 \%)$ and to a lesser extend to plagioclase $(30 \%)$ whilst apatite contributes for $4 \%$ only. For $\mathrm{Mg}$, the main contributors to the weathering solution are hornblende and biotite with $66 \%$ and $34 \%$, respectively.

- The current elemental fluxes from the hillside system are extremely low due to both high recharge and the inert lateritic materials. Out of the $77 \mathrm{~mol} / \mathrm{ha} / \mathrm{yr}$ of $\mathrm{Na}$ leached by chemical weathering, $72 \mathrm{~mol} / \mathrm{ha} / \mathrm{yr}$ and $5 \mathrm{~mol} /$ ha/yr can be attributed to the breakdown of plagiocalse (oligoclase, albite) and hornblende, respectively. Silica is the most important species to be exported out of the watershed with $300 \mathrm{~mol} / \mathrm{ha} / \mathrm{yr}$, attributed to plagioclase and kaolinite dissolution. $\mathrm{Al}\left(F_{\mathrm{Al} \text {,hill }}=2 \mathrm{~mol} / \mathrm{ha} / \mathrm{yr}\right)$ and $\mathrm{Ga}\left(F_{\mathrm{Ga}, \text { hill }}=15 \mathrm{mmol} / \mathrm{ha} / \mathrm{yr}\right)$ are exported from the lateritic weathering profile likely due to the dissolution of kaolinite crystals. Immobile elements at the hillside scale encompasses HREE, U, Th, $\mathrm{Zr}, \mathrm{Hf}, \mathrm{Nb}$. Ti is mobile with export flux of $20 \mathrm{mmol} / \mathrm{ha} / \mathrm{yr}$. Among redox-sensitive elements $(\mathrm{Fe}, \mathrm{V}, \mathrm{Cr}, \mathrm{Mn}, \mathrm{Ce})$, only $\mathrm{Ce}$ $\left(F_{\mathrm{Ce}, \text { hill }}=2 \mathrm{mmol} / \mathrm{ha} / \mathrm{yr}\right)$ and $\mathrm{Mn}\left(F_{\mathrm{Mn} \text {,hill }}=280 \mathrm{mmol} /\right.$ $\mathrm{ha} / \mathrm{yr}$ ) are exported out of the hillside system. Rb, Ni, 
$\mathrm{Cu}, \mathrm{Zn}$ are exported in the range of 10 to $100 \mathrm{mmol} / \mathrm{ha} /$ $\mathrm{yr}, \mathrm{Ba}$ and $\mathrm{Sr}$ in the range $200-300 \mathrm{mmol} / \mathrm{ha} / \mathrm{yr}$. LREE and $\mathrm{Y}$ are exported but in very low amounts (in the $\mu \mathrm{mol} / \mathrm{ha} / \mathrm{yr}$ to $\mathrm{mmol} / \mathrm{ha} / \mathrm{yr}$ range) without $\mathrm{Ce}$ fractionation.

- The element export by the stream can be sorted out by being (1) primarily controlled by the swamp $\left(80 \leqslant \% F_{\text {swamp }} \leqslant 100 \%\right)$ as $\mathrm{Th}, \mathrm{Zr}, \quad \mathrm{U}, \quad$ LREE, $\mathrm{HREE}+\mathrm{Y}, \mathrm{Cu}, \mathrm{Fe}, \mathrm{Cr}, \mathrm{V}, \mathrm{Zr}, \mathrm{Hf}, \mathrm{Nb}$, Ti and Al (2) significantly controlled $\left(60 \leqslant \% F_{\text {swamp }} \leqslant 80 \%\right)$ as $\mathrm{Na}, \mathrm{Rb}$, $\mathrm{Sr}, \mathrm{Mn}, \mathrm{Ni}, \mathrm{K}, \mathrm{Ca}, \mathrm{Ba}, \mathrm{Zn}$ and $\mathrm{Ga}$ (3) moderately controlled $\left(\% F_{\text {swamp }} \leqslant 60 \%\right)$ as $\mathrm{Mg}$, Co and $\mathrm{Si}$.

- The comparison of water budget and pore water composition within the mature ridge top weathering profiles of Nsimi and that immature of Mule Hole indicates that, at Nsimi, even with high discharge, the importance of the maturity of the weathering cover coupled with the hydrological functioning remains a fundamental forcing for the solute export, hence chemical weathering and the shape of the weathering front with a saprolite production rate of $2 \mathrm{~mm} / \mathrm{kyr}$ (against $22 \mathrm{~mm} / \mathrm{kyr}$ at Mule Hole) and a sharp weathering front.

- On a long-term basis ( $>1$ Myr), the assessment of the saprolite production rate infers that the chemical weathering has hardly changed for this deep mature cover developed on shield granito-gneissic rocks.

\section{ACKNOWLEDGEMENTS}

In Cameroon, the multidisciplinary research carried on the Nsimi watershed began in 1994 under the control of IRD and IRGM-CRH (Institut de Recherche Géologique et Minière/Centre de Recherche Hydrologique, Yaoundé, Cameroon). Apart from the specific support from the French Institute of Research for Development (IRD), our project benefited from funding from the National Programs PROSE/PEGI (Programme Sol Erosion/Programme Environnement Géosphère Intertropicale) and PNSE (Programme National Sol-Erosion) dedicated to a better understanding of the humid tropical ecosystems These programs were funded both by IRD and INSU/CNRS (Institut National des Sciences de l'Univers/Centre National de la Recherche Scientifique). In India, the multidisciplinary research carried on the Mule Hole watershed began in 2002 under the aegis of the IFCWS (Indo-French Cell forWater Sciences), joint laboratory IISc/IRD. Apart from the specific support from the French Institute of Research for Development (IRD), the Embassy of France in India and the Indian Institute of Science, our project benefited from the funding from IRD and INSU/CNRS (Institut National des Sciences de l'Univers/Centre National de la Recherche Scientifique) through the French programmes ECCO-PNRH (Ecosphère Continentale: Processus et Modélisation - Programme National Recherche Hydrologique), EC2CO (Ecosphère Continentale et Côtière) and ACI-Eau. It is also funded by the Indo-French programme IFCPAR (IndoFrench Center for the Promotion of Advanced ResearchW-3000). We thank the Karnataka Forest Department and the staff of the Bandipur National Park for all the facilities and support they provided. The long term monitoring on both Nsimi and Mule Hole SEW is supported by the project SOERE BVET (Service Observation Recherche en Environnement - Basins Versants Expérimentaux Tropicaux; http://bvet.omp.obs-mip.fr). The SEWs are also part of the SOERE French Resources for the Exploration of the Critical Zone (Réseau des Bassins Versants, http://www.allenvi.fr).
We thank Mathieu Zang, Mathurin Amougou, Patrice Messi, Claude Akono of the Nsimi village and Justin Nlozoa (IRGM$\mathrm{CRH}$ ) for the care that they took in setting up of the watershed and maintaining it. We are grateful to Michel Valladon and Bernard Reynier for their assistance during the ICP-MS measurements, Philippe De Perceval for microprobe analyses and C. Lagane for the major element analyses at GET (Géoscience Environnement Toulouse). Professor Shyamala Mani is acknowledged for her help with English copyediting.

Thanks to S.L. Brantley and S. Carretier for stimulating discussions about the development of weathering fronts in the Critical Zone.

We wish to express our sincere gratitude to J.R. Price, M. Widdowson and an anonymous reviewer for providing thorough and valuable reviews.

Dr. S. Krishnaswami is thanked for his editorial handling of this paper.

\section{REFERENCES}

Aleva G. J. J. (1994) Laterites. In Concepts, Geology, Morphology and Chemistry. ISRIC, Wageningen.

Anderson S. P., Bales R. C. and Duffy C. J. (2008) Critical zone observatories: building a network to advance interdisciplinary study of Earth surface processes. Mineral. Mag. 72, 7-10.

Anderson S. P., von Blanckenburg F. and White A. F. (2007) Physical and chemical controls on the critical zone. Elements $\mathbf{3}$, 315-319.

Balan E., Allard T., Fritsch E., Sélo M., Falguères C., Chabaux F., Pierret M.-C. and Calas G. (2005) Formation and evolution of lateritic profiles in the middle Amazon basin: insights from radiation-induced defects in kaolinite. Geochim. Cosmochim. Acta 69, 2193-2204.

Barbiéro L., Parate H. R., Descloitres M., Bost A., Furian S., Mohan Kumar M. S., Kumar C. and Braun J.-J. (2007) Using a structural approach to identify relationships between soil and erosion in a non-anthropic forested area, South India. Catena 70, 313-329.

Beauvais A. (1999) Geochemical mass balance of lateritization processes and climatic change signatures in weathering profiles overlain by ferricretes in Central Africa. Geochim. Cosmochim. Acta 63, 3939-3957.

Beauvais A. (2009) Ferricrete biochemical degradation on the rainforest-savannas boundary of Central African Republic. Geoderma 150, 379-388.

Berner R. A. (1978) Rate control of mineral dissolution under earth surface conditions. Am. J. Sci. 278, 1235-1252.

Bilong P., Eno Belinga S. M. and Volkoff B. (1992) Séquence d'évolution des paysages cuirassés et des sols ferrallitiques en zones forestières tropicales d'Afrique Centrale: place des sols a horizons d'argiles tachetées. C. R. Acad. Sci. Paris 314, 109115.

Bitom D., Volkoff B., Beauvais A., Seyler F. and Ndjigui P.-D. (2004) Rôle des héritages latéritiques et du niveau des nappes dans l'évolution des modelés et es sols en zone intertropicale forestière humide. C. R. Acad. Sci. Paris 336, 1161-1170.

Boeglin J. L. and Probst J. L. (1998) Physical and chemical weathering rates and $\mathrm{CO}_{2}$ comsumption in a tropical lateritic environment: the upper Niger Basin. Chem. Geol. 148, 137-156.

Brantley S. L. and Lebedeva M. (2011) Learning to read the chemistry of regolith to understand the critical zone. Annu. Rev. Earth Planet. Sci. 39, 387-416.

Brantley S. L. (2008) Understanding soil time - perspectives geology. Science 321, 1454-1455. 
Brantley S. L. (2010) Rock to regolith - focus news and views. Nat. Geosci. 3, 305-306.

Brantley S. L., Goldhaber M. B. and Ragnarsdottir K. V. (2007) Crossing disciplines and scales to understand the critical zone. Elements 3, 307-314.

Brantley S. L. and White A. F. (2009) Approaches to modeling weathered regolith. In Reviews in Mineralogy and Geochemistry. Mineralogical Society of America, pp. 435-484.

Braun J.-J., Descloitres M., Riotte J., Fleury S., BarbiÈro L., Boeglin J.-L., Violette A., Lacarce E., Ruiz L., Sekhar M., Mohan Kumar M. S., Subramanian S. and Duprè B. (2009) Regolith mass balance inferred from combined mineralogical, geochemical and geophysical studies: Mule Hole gneissic watershed, South India. Geochim. Cosmochim. Acta 73, 935961.

Braun J.-J., Ndam Ngoupayou J. R., Viers J., Dupre B., Bedimo Bedimo J. P., Boeglin J. L., Robain H., Nyeck B., Freydier R., Sigha Nkamdjou L., Rouiller J. and Muller J.P. (2005) Present weathering rates in a humid tropical watershed: Nsimi site (South Cameroon). Geochim. Cosmochim. Acta 69, 357-387.

Braun J.-J., Viers J., Dupre B., Polve M., Ndam J. and Muller J.-P. (1998) Solid/Liquid REE fractionation in the lateritic system of Goyoum, East Cameroon: the implication for the present dynamics of the soil covers of the humid tropical regions. Geochim. Cosmochim. Acta 62, 273-299.

Brimhall G. H., Lewis C. J., Ague J. J., Dietrich W. E., Hampel J., Teague T. and Rix P. (1988) Metal enrichment in bauxites by deposition of chemically mature aeolian dust. Nature 333, 819824.

Brimhall G. H., Lewis C. J., Ford C., Bratt J., Taylor G. and Warin O. (1991) Quantitative geochemical approach to pedogenesis: importance of parent material reduction, volumetric expansion and eolian influx in laterization. Geoderma 51, 51-91.

Cary L., Alexandre A., Meunier J.-D., Boeglin J.-L. and Braun J. J. (2005) Contribution of phytoliths to the suspended load of biogenic silica in the Nyong basin rivers (Cameroon). Biogeochemistry 74, 101-114.

Chabaux F., Dequincey O., Leveque J.-J., Leprun J.-C., Clauer N., Riotte J. and Paquet H. (2003) Tracing and dating recent chemical transfers in weathering profiles by trace-element geochemistry and 238U-234U-230Th disequilibria: the example of the Kaya lateritic toposequence (Burkina-Faso). C. R. Geosci. 335, 1219-1231.

Chadwick O. A. and Chorover J. (2001) The chemistry of pedogenic thresholds. Geoderma 100, 321-353.

Delattre S., Utsunomiya S., Ewing R., Boeglin J. L., Braun J.-J., Balan E. and Calas G. (2007) Dissolution of radiation-damaged zircon in lateritic soils. Am. Mineral. 92, 1978-1989.

Dequincey O., Chabaux F., Clauer N., Sigmarsson O., Liewig N. and Leprun J. C. (2002) Chemical mobilizations in laterites: evidence from trace elements and 238U-234U-230Th disequilibria. Geochim. Cosmochim. Acta 66, 1197-1210.

Descloitres M., Ruiz L., Sekhar M., Legchenko A., Braun J J., Mohan Kumar M. S. and Subramanian S. (2007) Characterization of seasonal local recharge using electrical resistivity tomography and magnetic resonance sounding. Hydrol. Process. 22, 384-394.

Dosseto A., Turner S. P. and Chappell J. (2008) The evolution of weathering profiles through time: new insights from uraniumseries isotopes. Earth Planet. Sci. Lett. 274, 359-371.

Edmond J. M., Palmer M. R., Measures C. I., Grant B. and Stallard R. F. (1995) The fluvial geochemistry and denudation rate of the Guayana Shield in Venezuela, Colombia and Brazil. Geochim. Cosmochim. Acta 59, 3301-3325.
Fritsch, P., 1978. Chronologie relative des formations cuirassees et analyses geographiques des facteurs du cuirassement au Cameroun. Trav. Doc. CEGET, Bordeaux, Bordeaux, pp. 115-132.

Godderis Y., Donnadieu Y., Tombozafy M. and Dessert C. (2008) Shield effect on continental weathering: implication for climatic evolution of the Earth at the geological timescale. Geoderma 145, 439-448.

Goddéris Y., Roelandt C., Schott J., Pierret M.-C. and François L. M. (2009) Towards an integrated model of weathering, climate, and biospheric processes (ed. M. S. o. America). Reviews in Mineralogy \& Geochemistry, pp. 411-434.

Gunnell Y. (1998) Present, past and potential denudation rates: is there a link? Tentative evidence from fission-track data, river sediment loads and terrain analysis in the South Indian shield. Geomorphology 25, 135-153.

Gunnell Y., Gallagher K., Carter A., Widdowson M. and Hurford A. J. (2003) Denudation history of the continental margin of western peninsular India since the early Mesozoic - reconciling apatite fission-track data with geomorphology ${ }^{*} 1$. Earth Planet. Sci. Lett. 215, 187-201.

Javeed, Y., 2010. Analysis of groundwater dynamics in semi-arid regions: effect of rainfall variability and pumping, Ph.D., Civil Engineering. Indian Institute of Science, Bangalore, India.

Javeed Y., Sekhar M., Bandyopadhyay S. and Mangiarotti S. (2009) EOF and SSA analyses of hydrological time series to assess effects of climatic variability and land use effects: a case study in the Kabini river basin in south India. IAHS publication 329, 167-177.

Kisakurek B., Widdowson M. and James R. H. (2004) Behaviour of $\mathrm{Li}$ isotopes during continental weathering: the Bidar laterite profile, India. Chem. Geol. 212, 27-44.

Lin H. (2010) Earth's Critical Zone and hydropedology: concepts, characteristics and advances. Hydrol. Earth Syst. Sci. 14, 25-45.

Maréchal J. C., Braun J. J., Riotte J., Bedimo Bedimo J.-P. and Boeglin J. L. (2011a) Hydrologic processes of a rainforest headwater swamp from natural chemical tracing in Nsimi watershed, Cameroon. Hydrol. Process. http://dx.doi.org/ 10.1002/hyp.7989.

Maréchal J. C., Riotte J., Lagane C., Subramanian S., Kumar C., Ruiz L., Audry S., Varma M. R. R. and Braun J. J. (2011b) Deep groundwater flow as the main pathway for chemical outputs in a small headwater watershed. Appl. Geochem. 26, S94-S96.

Marechal J. C., Varma M. R. R., Riotte J., Vouillamoz J. M., Kumar M. S. M., Ruiz L., Sekhar M. and Braun J. J. (2009) Indirect and direct recharges in a tropical forested watershed: Mule Hole, India. J. Hydrol. 364, 272-284.

Migon P. (2006) Granite Landscapes of the World. Oxford University Press.

Migon P. (2009) Are any granite landscape distinctive of the humid tropics? Reconsidering multiconvex topographies. Singap. J. Trop. Geogr. 30, 327-342.

Morin, S., 1989. Hautes terres et bassins de l'Ouest Cameroun. Etude geomorphologique, Dpt. Geography. Univ. Bordeaux III, p. 1190.

Nahon D. (1991) Introduction to the Petrology of Soil and Chemical Weathering. John Wiley and Sons, New York, 313p..

Nash D. J. and McLaren S. J. (2007) Geochemical Sediments and Landscapes. Blackwell, Oxford.

Ngomanda A., Jolly D., Bentaleb I., Chepstow-Lusty A., Makaya M. v., Maley J., Fontugne M., Oslisly R. and Rabenkogo N. (2007) Lowland rainforest response to hydrological changes during the last 1500 years in Gabon, Western Equatorial Africa. Quatern. Res. 67, 411-425.

Ngomanda A., Neumann K., Schweizer A. and Maley J. (2009) Seasonality change and the third millennium BP rainforest 
crisis in southern Cameroon (Central Africa). Quatern. Res. 71, 307-318.

Oh N.-H. and Richter D. D. (2005) Elemental translocation and loss from three highly weathered soil-bedrock profiles in the southeastern United States. Geoderma 126, 5-25.

Oliva P., Viers J., Dupre B., Fortune J. P., Martin F., Braun J. J., Nahon D. and Robain H. (1999) The effect of organic matter on chemical weathering: study of a small tropical watershed: nsimizoetele site, cameroon. Geochim. Cosmochim. Acta 63, 40134035.

Parrish J. T., Ziegler A. M. and Scotese C. R. (1982) Rainfall patterns and the distribution of coals and evaporites in the Mesozoic and Cenozoic. Pal. Pal. Pal. 40, 67-101.

Pavich M. J. (1989) Regolith residence time and the concept of surface age of the Piedmont "Peneplain". Geomorphology 2, 181-196.

Poitrasson F., Viers J., Martin F. and Braun J.-J. (2008) Limited iron isotope variations in recent lateritic soils from Nsimi, Cameroon: implications for the global Fe geochemical cycle. Chem. Geol. 253, 54-63.

Price J. R., Heitmann N., Hull J. and Szymanski D. (2008) Longterm average mineral weathering rates from watershed geochemical mass balance methods: using mineral modal abundances to solve more equations in more unknowns. Chem. Geol. 254, 36-51.

Retallack G. L. (2010) Lateritization and bauxitization Events. Econ. Geol. 105, 655-667.

Riebe C. S., Kirchner J. W. and Finkel R. C. (2003) Long-term rates of chemical weathering and physical erosion from cosmogenic nuclides and geochemical mass balance. Geochim. Cosmochim. Acta 67, 4411-4427.

Ruiz L., Varma M. R. R., Kumar M. S. M., Sekhar M., Marechal J. C., Descloitres M., Riotte J., Kumar S., Kumar C. and Braun J. J. (2010) Water balance modelling in a tropical watershed under deciduous forest (Mule Hole, India): regolith matric storage buffers the groundwater recharge process. J. Hydrol. 380, 460-472.

Schefusz E., Schouten S. and Schneider R. R. (2005) Climatic controls on central African hydrology during the past 20,000[thinsp]years. Nature 437, 1003-1006.

Schellmann W. (1986) A new definition of laterite. In Lateritisation Processes (ed. P. K. Banerjiee). Memoir of the Geological Survey of India, pp. 1-7.

Segalen P. (1967) Les sols et la géomorphologie du Cameroun. Cah. ORSTOM, Série Pédol. 5(2), 137-188.

Soumya B. S., Sekhar M., Riotte J., Audry S., Lagane C. and Braun J. J. (2011) Inverse models to analyze the spatiotemporal variations of chemical weathering fluxes in a granito-gneissic watershed: Mule Hole, South India. Geoderma 165, 12-24.

Soumya B. S., Sekhar M., Riotte J. and Braun J. J. (2009) Nonlinear regression model for spatial variation in precipitation chemistry for South India. Atmos. Environ. 43, 1147-1152.

Tarantola A. and Valette B. (1982) Generalized nonlinear inverse problems solved using the least squares criterion. Rev. Geophys. Space Phys. 20, 219-232.

Tardy Y. (1993) Pétrologie des latérites et des sols tropicaux. Masson, Paris.

Tardy, Y., Roquin, C., 1998. Dérive des continents - Paléoclimats et altérations tropicales. BRGM Editions, Orléans.
Thomas M. F. (1994) Geomorphology in the tropics. A study of weathering and denudation in low latitudes. John Wiley \& Sons.

Thomas M. F. (2006) Lessons from the tropics for a global geomorphology. Singap. J. Trop. Geogr. 27, 11-127.

USDA, 1999. Soil Taxonomy: A Basic System of Soil Classification for Making and Interpreting Soil Surveys - Soil Survey Staff. USDA NRCS, Washington, USA.

Velbel M. A. (1985) Geochemical mass balances and weathering rates in forested watershed of the southern Blue Ridge. Am. J. Sci. 285, 904-930.

Velbel M. A. (1993) Temperature dependence of silicate weathering in nature: how strong a negative feedback on long-term accumulation of atmospheric $\mathrm{CO}_{2}$ and global greenhouse warming? Geology 21, 1059-1062.

Viers J., Dupre B., Polve M., Schott J., Dandurand J. L. and Braun J. J. (1997) Chemical weathering in the drainage basin of a tropical watershed (Nsimi-Zoetele site, Cameroon): comparison between organic poor and organic rich waters. Chem. Geology 140, 181-206.

Viers J., Oliva P., Nonell A., Gélabert A., Sonke J. E., Freydier R., Gainville R. and Dupré B. (2007) Evidence of $\mathrm{Zn}$ isotopic fractionation in a soil-plant system of a pristine tropical watershed (Nsimi, Cameroon). Chem. Geol. 239, 124-137.

Viers J. and Wasserburg G. J. (2004) Behavior of Sm and Nd in a lateritic soil profile. Geochim. Cosmochim. Acta 68, 2043-2054.

Violette A., Godderis Y., Marechal J. C., Riotte J., Oliva P., Kumar M. S. M., Sekhar M. and Braun J. J. (2010) Modelling the chemical weathering fluxes at the watershed scale in the Tropics (Mule Hole, South India): relative contribution of the smectite/kaolinite assemblage versus primary minerals. Chem. Geol. 277, 42-60.

Weldeab S., Schneider R. R., Kölling M. and Wefer G. (2005) Holocene African droughts relate to eastern equatorial Atlantic cooling. Geology 33, 981-984.

West A. J., Galy A. and Bickle M. (2005) Tectonic and climatic controls on silicate weathering. Earth Planet. Sci. Lett. 235, 211-228.

White, A.F., 2008. Quantitative Approaches to Characterizing Natural Chemical Weathering Rates. In Kinetics of WaterRock Interaction (eds. S. L. Brantley, J. D. Kubicki and A.F. White). Springer, New York, pp. 469-543.

White P. J. and Broadley M. R. (2001) Chloride in soils and its uptake and movement within the plant: a review. Ann. Bot. 88, 967-988.

Widdowson M. (2003) Ferricrete. In Encyclopedia of Geomorphol$o g y$ (ed. A. S. Goudie). Routledge, London, pp. 365-367.

Widdowson M. (2007) Laterite and ferricrete. In Geochemical Sediments and Landscapes (eds. D. J. Nash and S. J. McLaren). Blackwell Publishing Ltd., p. 488pp..

Wimpenny J., Gannoun A., Burton K. W., Widdowson M., James R. H. and Gíslason S. R. (2007) Rhenium and osmium isotope and elemental behaviour accompanying laterite formation in the Deccan region of India. Earth Planet. Sci. Lett. 261, 239 258. 